\section{Pacific Northwest}

National Laboratory

Operated by Battelle for the

U.S. Department of Energy

\title{
Liquid Waste Certification Plan for Pacific Northwest National Laboratory
}

\author{
M.J. McCarthy \\ M.Y. Ballinger
}

June 2000

Prepared for the U.S. Department of Energy under Contract DE-AC06-76RL01830 


\section{LIQUID WASTE CERTIFICATION PLAN FOR PACIFIC NORTHWEST NATIONAL LABORATORY Rev. 2, June 2000}
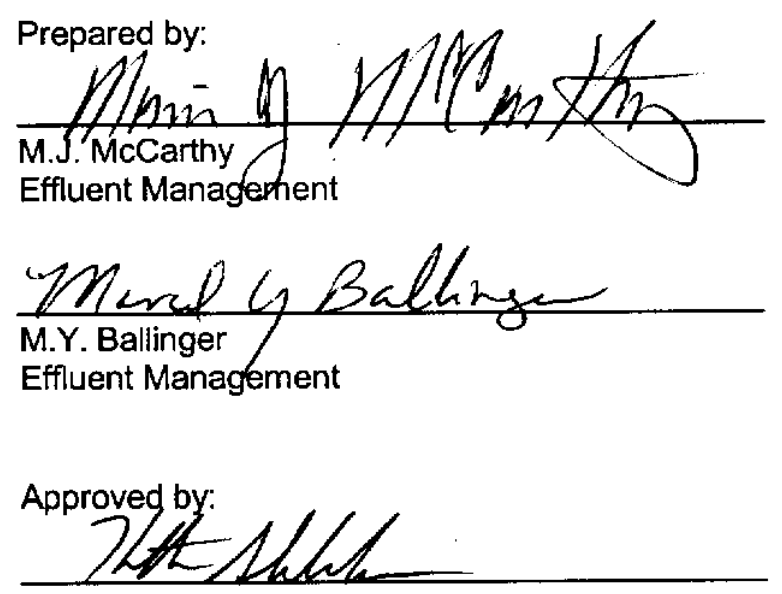

K.D. Shields, Task Leader, Liquid Effluent Management

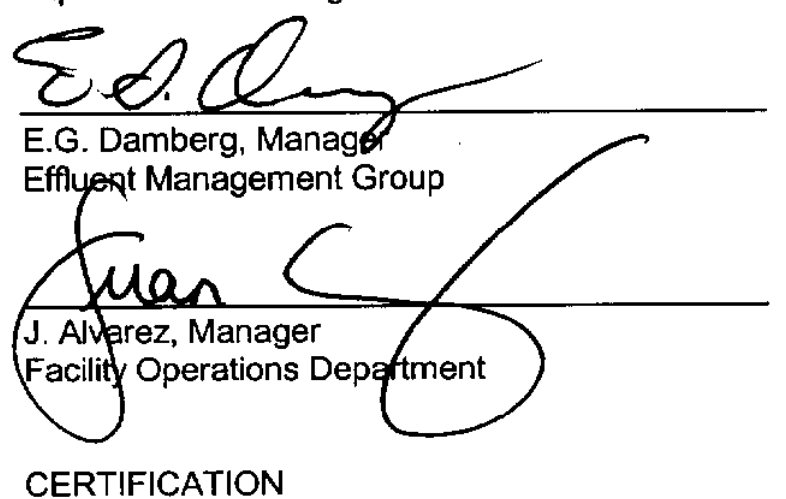

I certify that, to the best of my knowledge, the information contained in the Pacific Northwest National Laboratory Liquid Waste Certification Plan accurately reflects discharges to the Process and Retention Process Sewers.

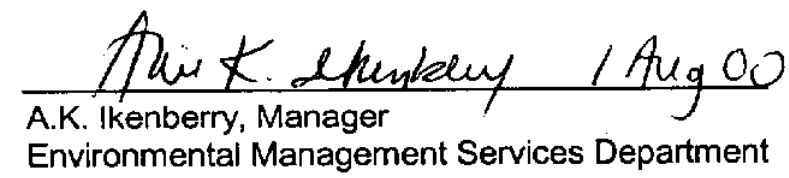




\title{
Liquid Waste Certification Plan for Pacific Northwest National Laboratory
}

\section{Revision 2}

\author{
M. J. McCarthy \\ M. Y. Ballinger
}

June 2000

Prepared for

the U.S. Department of Energy

under Contract DE-AC06-76RLO 1830

Pacific Northwest National Laboratory

Richland, Washington 99352 


\title{
DISCLAIMER
}

This report was prepared as an account of work sponsored by an agency of the United States Government. Neither the United States Government nor any agency thereof, nor Battelle Memorial Institute, nor any of their employees, makes any warranty, express or implied, or assumes any legal liability or responsibility for the accuracy, completeness, or usefulness of any information, apparatus, product, or process disclosed, or represents that its use would not infringe privately owned rights. Reference herein to any specific commercial product, process, or service by trade name, trademark, manufacturer, or otherwise does not necessarily constitute or imply its endorsement, recommendation, or favoring by the United States Government or any agency thereof, or Battelle Memorial Institute. The views and opinions of authors expressed herein do not necessarily state or reflect those of the United States Government or any agency thereof.

\author{
PACIFIC NORTHWEST NATIONAL LABORATORY \\ operated by \\ BATTELLE \\ for the \\ UNITED STATES DEPARTMENT OF ENERGY \\ under Contract DE-AC06-76RL01830
}

Printed in the United States of America
Available to DOE and DOE contractors from the Office of Scientific and Technical Information,
P.O. Box 62, Oak Ridge, TN 37831-0062;
ph: (865) 576-8401
fax: $(865) 576-5728$
email: reports@adonis.osti.gov

\footnotetext{
Available to the public from the National Technical Information Service, U.S. Department of Commerce, 5285 Port Royal Rd., Springfield, VA 22161 ph: (800) 553-6847 fax: $(703) 605-6900$ email: orders@ntis.fedworld.gov online ordering: http://www.ntis.gov/ordering.htm
}

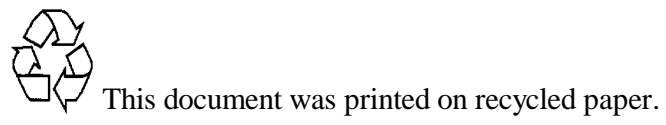




\section{Executive Summary}

The Pacific Northwest National Laboratory operates a number of research and development facilities for the U.S. Department of Energy (DOE) in the Hanford Site's 300 Area. The liquid wastes from these facilities are discharged to four liquid effluent systems: the Sanitary Waste System (SNS), the Process Sewer (PS), the Retention Process Sewer (RPS), and the 325 Radioactive Liquid Waste System. The wastewater from the PS and RPS systems is treated by the 300 Area Treated Effluent Disposal Facility and discharged to the Columbia River via a National Pollutant Discharge Elimination System-permitted outfall. The SNS discharges to the City of Richland Publicly Owned Treatment Works under a contract with the DOE. The RLWS wastewater is transported to tanks in the 200 Area. Neither of these two systems interface with the 300 Area TEDF.

The following active Pacific Northwest facilities currently have the capability to discharge liquid waste to the 300 Area PS or RPS systems:

- 306W Materials Development Laboratory

- 318 Radiological Calibrations Laboratory

- 320 Analytical and Nuclear Research Laboratory

- 323 Mechanical Properties Laboratory

- 325 Radiochemical Processing Laboratory

- 326 Materials Sciences Laboratory

- 329 Chemical Sciences Laboratory

- 331 Life Sciences Laboratory I
- 331D Biomagnetic Effects Laboratory

- 331G Interim Tissue Repository

- 331H Aerosol Wind Tunnel Research Facility

- 336 High-Bay Testing Facility

- 337 Technical Management Center

- 338 Prototype Engineering Laboratory

- 3720 Environmental Sciences Laboratory

- 3730 Gamma Irradiation Facility.

The following data are provided in this report for each facility listed above in accordance with RCP-310, 300 LEF Project Administration Procedures, Section 3.04, Liquid Waste Certification Program, Subsection 4.3 "Liquid Waste Certification Plan Content":

- a brief, general description of each Pacific Northwest building that discharges liquid waste to the PS or RPS

- a description of the types of activities that generate the effluent

- information concerning effluent constituents and the source of this information

- estimates of flow rates

- rationale for connections to the RPS. 
This page intentionally left blank.

Issued: June 2000

PNNL-13276, Rev. 2

Supersedes: Rev. 1

Page iv 


\section{Contents}

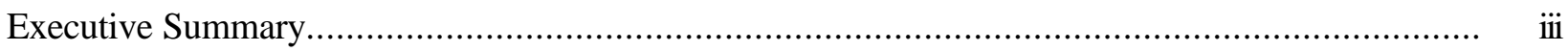

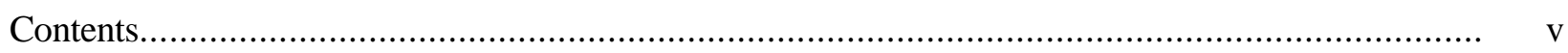

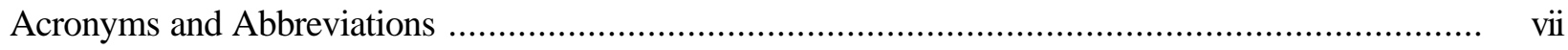

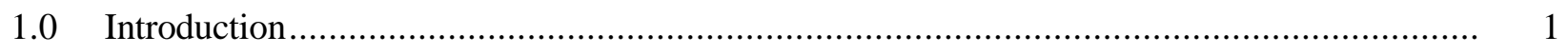

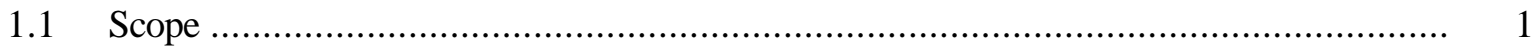

1.2 Engineered and Administrative Controls ............................................................. 2

1.3 Effluent Sampling and Monitoring .................................................................... 4

1.4 Research and Development Activities.................................................... 5

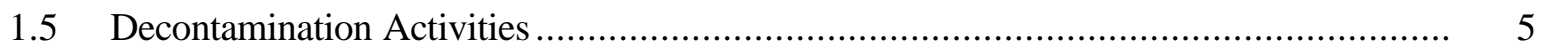

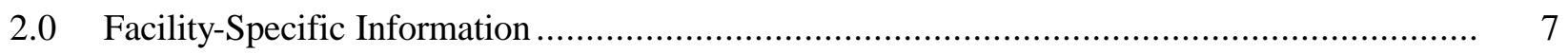

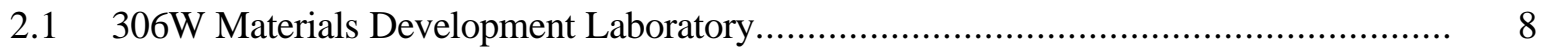

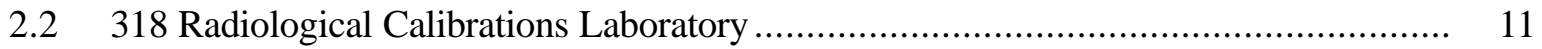

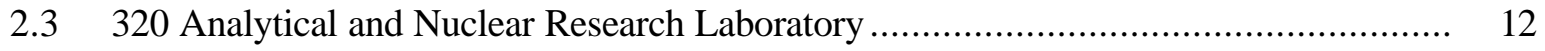

2.4323 Mechanical Properties Laboratory.............................................................. 15

2.5325 Radiochemical Processing Laboratory ....................................................... 16

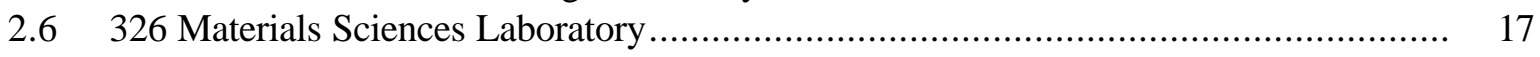

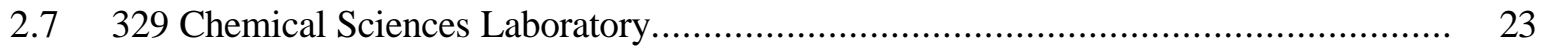

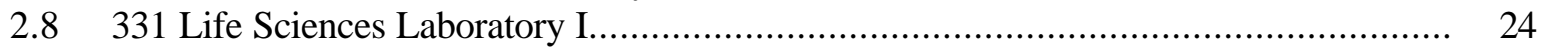

2.9 331D Biomagnetic Effects Laboratory............................................................ 28

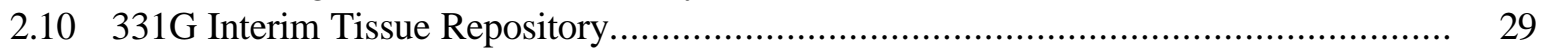

$2.11331 \mathrm{H}$ Aerosol Wind Tunnel Research Facility ..................................................... 29

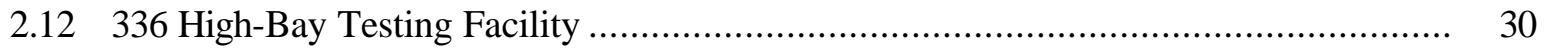

2.13337 Technical Management Center...................................................................... 31

2.14338 Prototype Engineering Laboratory........................................................ 31

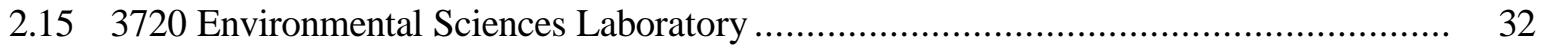

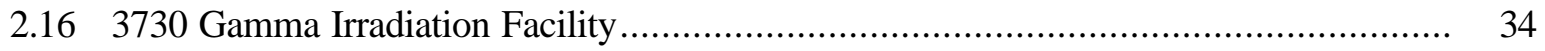

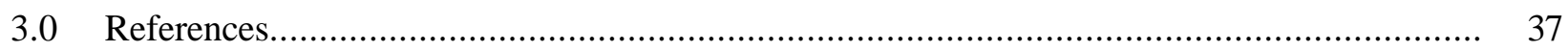

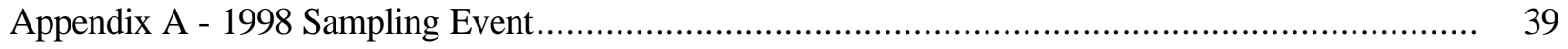

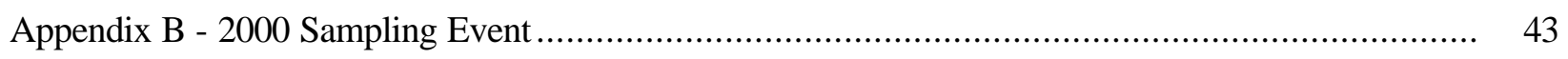

Appendix C - Treated Effluent Disposal Facility Waste Acceptance Criteria ............................ 47 


\section{Tables}

2.1 Constituents Detected in the 306W Materials Development Laboratory PS Samples............. 10

2.2 Constituents Detected in the 320 Analytical and Nuclear Research Laboratory PS Samples ..... 13

2.3 Constituents Detected in 325 Radiochemical Processing Laboratory RPS Samples............... 18

2.4 Constituents Detected in the 326 Materials Sciences Laboratory PS Samples .................... 19

2.5 Constituents Detected in the 326 Materials Sciences Laboratory RPS Samples.................... 21

2.6 Constituents Detected in 331 Life Sciences Laboratory I PS Samples ............................ 26

2.7 Constituents Detected in the 3720 Environmental Sciences Laboratory PS Samples .............. 33 


\section{Acronyms and Abbreviations}

\begin{tabular}{|c|c|}
\hline DCG & Derived Concentration Guideline \\
\hline DOE & U.S. Department of Energy \\
\hline dpm & disintegrations per minute \\
\hline GEA & Gamma Energy Analysis \\
\hline gpm & gallons per minute \\
\hline HEPA & high-efficiency particulate air \\
\hline $\mathrm{mg} / \mathrm{L}$ & milligrams per liter \\
\hline NPDES & National Pollutant Discharge Elimination System \\
\hline $\mathrm{pCi} / \mathrm{L}$ & picocuries per liter \\
\hline $\mathrm{ppb}$ & parts per billion \\
\hline PS & Process Sewer \\
\hline $\mathrm{R} \& \mathrm{D}$ & research and development \\
\hline RLWS & Radioactive Liquid Waste System \\
\hline RPS & Retention Process Sewer \\
\hline SBMS & Standards-Based Management System \\
\hline SNS & Sanitary Waste System \\
\hline TEDF & Treated Effluent Disposal Facility \\
\hline TOC & Total Organic Carbon \\
\hline$\mu \mathrm{g} / \mathrm{L}$ & microgram per liter \\
\hline
\end{tabular}

$\mu \mathrm{mhos} / \mathrm{cm}$ micromhos per centimeter; a mho is the inverse of an ohm and has units of amperes/volts 
This page intentionally left blank.

Issued: June 2000

PNNL-13276, Rev. 2

Supersedes: Rev. 1

Page viii 


\subsection{Introduction}

The Pacific Northwest National Laboratory (Pacific Northwest) operates a number of research and development (R\&D) facilities for the U.S. Department of Energy (DOE) on the Hanford Site's 300 Area. The liquid wastes from these facilities are discharged to four liquid effluent systems: the Sanitary Waste System (SNS), the Process Sewer (PS), the Retention Process Sewer (RPS), and the 325 Radioactive Liquid Waste System (RLWS). ${ }^{(a)}$ The wastewater from the PS and RPS systems is treated by the 300 Area Treated Effluent Disposal Facility (TEDF) and discharged to the Columbia River via a National Pollutant Discharge Elimination System- (NPDES)-permitted outfall. The SNS discharges to the City of Richland Publicly Owned Treatment Works under a contract with the DOE. The RLWS wastewater is transported to tanks in the 200 Area. Neither of these two systems interface with the 300 Area TEDF.

The NPDES permit specifies limits of chemical constituents and requires "proper operation and maintenance" of the TEDF. To meet permit requirements, Fluor Hanford, operator of the TEDF, has developed administrative controls for all waste generators who discharge to the 300 Area TEDF. These administrative controls, that are specified in RCP-310, 300 LEF Project Administration Procedures, require that a Liquid Waste Certification Plan be prepared for facilities that routinely discharge to the TEDF. Pacific Northwest published the original Liquid Waste Certification Plan for Pacific Northwest National Laboratory in May 1996. Addendums to the plan were provided in 1997 and 1998. The plan was updated to replace the previous submitted plans and addendums in 1999. This plan is a revision to the 1999 plan.

This Liquid Waste Certification Plan covers all Pacific Northwest 300 Area facilities that discharge to the PS or RPS. Liquid effluent discharges from these buildings are centrally managed. Under normal operating conditions, the combined discharge from all Pacific Northwest facilities complies with the TEDF Waste Acceptance Criteria.

\subsection{Scope}

The following sections discuss the purpose and scope of this Liquid Waste Certification Plan. The discharges from all Pacific Northwest facilities are managed by a common set of engineered and administrative controls, which are described in Section 1.2. Liquid effluent sampling has been performed to characterize PS and RPS waste streams from the Pacific Northwest facilities that are considered the major potential contributors (considering both flow rate and potential chemical content) to the TEDF. Section 1.3 describes this effort and the systems that remain in place to provide sampling and monitoring capabilities. Section 1.4 provides a basis for the facility-specific information given in Section 2.0.

Section 1.5 addresses the release of rinse water from minor skin decontamination activities to the PS.

(a) The RLWS as a 300 Area-wide system is no longer operable. A tank system has been set up within the 325 Building to provide for periodic transfers of radioactive liquid wastes to the 200 Area Tank Farms. This system is called the 325 RLWS. 
The following active Pacific Northwest facilities currently have the capability to discharge liquid waste to the 300 Area PS or RPS systems:

- 306W Materials Development Laboratory

- 318 Radiological Calibrations Laboratory

- 320 Analytical and Nuclear Research Laboratory

- 323 Mechanical Properties Laboratory

- 325 Radiochemical Processing Laboratory

- 326 Materials Sciences Laboratory

- 329 Chemical Sciences Laboratory

- 331 Life Sciences Laboratory I

- 331D Biomagnetic Effects Laboratory

- 331G Interim Tissue Repository

- 331H Aerosol Wind Tunnel Research Facility

- 336 High-Bay Testing Facility

- 337 Technical Management Center

- 338 Prototype Engineering Laboratory

- 3720 Environmental Sciences Laboratory

- 3730 Gamma Irradiation Facility.

The following Pacific Northwest facilities, which are connected to the PS, have been vacated and no longer generate liquid effluent discharges. Therefore, these facilities are not addressed further in this plan:

- 303J Material Storage Building

- 314 Engineering Development Laboratory

- 331E Greenhouse (only concrete pad remaining)

- 3708 Radioanalytical Laboratory

- 3745A Electron Accelerator Facility

- 3745B Positive Ion Accelerator Facility.

In addition, the 305B Hazardous Waste Storage Facility has a sump connected to the PS. However, its pump has been electrically disconnected and no discharges are provided to the PS. Three facilities, the 324 Waste Technology Engineering Laboratory, 327 Post-Irradiation Testing Laboratory, and 3746A Radiological Physics Laboratory, have been transferred to other Hanford Site contractors within the past 4 years.

\subsection{Engineered and Administrative Controls}

Pacific Northwest uses engineered controls when possible to ensure compliance with the TEDF Waste Acceptance Criteria. Examples of these controls include plugging or capping unnecessary sewer access points and ensuring that normally clean streams that may contain radioactive materials during 
upset conditions are routed to the RPS, which has diversion capability. Timely notification is made to the TEDF of any upset or noncompliant discharge.

Pacific Northwest has developed a Standards-Based Management System (SBMS), a Web-based system that communicates Laboratory-wide standards, policies, procedures, and guidelines. Procedures and guidelines related to discharges are contained in the SBMS subject area Managing Liquid Effluents (http://sbms.pnl.gov/standard/0q/0q00t010.htm). In this subject area, procedures are provided for planning for liquid effluents, disposing of nonradioactive liquid effluents, disposing of radioactive liquid effluents, and managing liquid waste disposal systems. The following are key elements:

- Releases to liquid waste systems are managed to comply with applicable local, state, and federal requirements.

- Releases to the 300 Area PS or RPS must comply with the TEDF Waste Acceptance Criteria Program, which includes a process to consider waivers from the Waste Acceptance Criteria on a caseby-case basis.

- Pacific Northwest's Environmental Management Services staff perform waste designation to determine whether waste is regulated (State of Washington Dangerous Waste/Federal Resource Conservation and Recovery Act) or nonregulated.

- If liquid waste is designated as nonregulated, Pacific Northwest's Effluent Management staff determine whether the material may be disposed to the PS or RPS, based on the Waste Acceptance Criteria and treatability at the TEDF.

- All sewer system access points in laboratories, shops, and associated areas must be labeled to identify the sewer that the access point serves.

- When practical, engineered controls shall be used to prevent accidental release to the PS or RPS.

Training for Pacific Northwest staff is identified and implemented through the process described in the SBMS subject area Training and Qualification for Staff (http://sbms.pnl.gov/standard/1e/1e00t010.htm). For staff who work with hazardous or radioactive materials, training is also required through the SBMS subject area Working with Chemicals (http://sbms.pnl.gov/standard/03/0300t010.htm). This subject area includes procedures and guidelines for planning to use chemicals, acquiring and storing chemicals, using hazardous chemicals, and disposing of chemical waste. The following are key elements:

- Cradle-to-grave management of chemicals must be planned for, including acquisition, use, storage, and disposal of chemicals.

- An inventory process is used to track chemicals in Pacific Northwest's Chemical Management System. 
- All chemicals must be kept in storage except when work is in progress. Storage areas do not include bench tops or fume hoods unless specifically designated as such (this subject area contains an exhibit "How to Store Chemicals").

- Spill response materials must be available for all storage areas [more information is available in the SBMS subject area Spill Response (http://sbms.pnl.gov/standard/0e/0e00t010.htm)].

- Staff must manage and dispose of chemical waste in compliance with the SBMS subject areas Managing Liquid Effluents, Managing Nonradioactive Chemical Waste (http://sbms.pnl.gov/standard/0f/0f00t010.htm), and Waste Minimization and Pollution Prevention (http://sbms.pnl.gov/standard/0z/0z00t010.htm). These subject areas provide procedures and guidelines on acquiring and storing chemicals, disposing of chemical waste, and training/awareness for use of hazardous chemicals.

\subsection{Effluent Sampling and Monitoring}

Effluent sampling was performed in 1994 and 1995 (Thompson et al. 1997) to characterize liquid wastes discharged to the PS and RPS from the Pacific Northwest facilities that were considered to be the major contributors to the TEDF. Facilities were selected according to their potential for discharging chemicals to the TEDF, and are also the major flow contributors from Pacific Northwest. This sampling effort was discontinued at the beginning of Fiscal Year 1995, but the sampling stations remain in standby to be used when needed to determine the source of discharges of concern to the TEDF or to periodically confirm that discharges remain low. For example, sampling was conducted in May 1998 from each of the dedicated sampling stations to affirm that discharges were similar to those characterized in the earlier campaign (see Appendix A) and sampling was conducted in February 2000 to aid in identifying sources of elevated gross alpha and tritium activity at TEDF (see Appendix B). The facilities with dedicated sampling stations are the

- 320 Analytical and Nuclear Research Laboratory

- 325 Radiochemical Processing Laboratory

- 326 Materials Sciences Laboratory

- 329 Chemical Sciences Laboratory

- 331 Life Sciences Laboratory I ${ }^{(a)}$

- 3720 Environmental Sciences Laboratory.

Each sampling station consists of a refrigerated sampler, flow meter, $\mathrm{pH}$ meter, and conductivity meter. The refrigerated samplers, which are currently in standby, have the ability to collect flowproportional composite samples. Flow, $\mathrm{pH}$, and conductivity data continue to be monitored centrally via the Facility Management Control System at four of these facilities (320 Analytical and Nuclear Research

(a) The sampling system at the 331 Building is temporarily out of service and is being repositioned following facility piping modifications. 
Laboratory, 325 Radiochemical Processing Laboratory, 326 Materials Sciences Laboratory, and 329 Chemical Sciences Laboratory). Data collection at the 331 Life Sciences Laboratory I and 3720 Environmental Sciences Laboratory is provided via stand-alone data-acquisition equipment.

Sample ports were installed at several locations where the potential for discharges containing hazardous constituents was determined to be small. These locations include the 318 Radiological Calibrations Laboratory and 3730 Gamma Irradiation Facility. These sample ports allow the use of portable, time-proportional sampling equipment, but have no continuous monitoring capabilities. The remaining facilities were determined to have minimal risk of discharges of concern to the TEDF and do not have dedicated sampling capabilities. However, sampling via portable samplers may be possible at some locations if needed.

\subsection{Research and Development Activities}

Activities in individual facilities range from primarily administrative to laboratory and pilot-scale R\&D. R\&D activities include radioactive and chemical waste characterization, fluid dynamics research, mechanical property testing, and dosimetry research. R\&D work is performed on a project basis and projects are evaluated for a number of factors, including environmental risk, before being initiated. Projects are primarily laboratory-scale, with some pilot-scale activities. A wide variety of chemicals and radioactive materials may be used, resulting in the generation of widely varying liquid wastes. The engineered and administrative controls used to ensure adequate disposal of the wastes are described in Section 1.2.

\subsection{Decontamination Activities}

Pacific Northwest plans to release rinse water from minor skin decontamination activities to the PS for treatment at the TEDF. Rinse water releases to the TEDF will be limited to skin decontamination events where the beta/gamma activity is less than 34,000 disintegrations per minute (dpm)/probe area [equivalent to 1,000 picocuries per liter ( $\mathrm{pCi} / \mathrm{L}$ ), the Derived Concentration Guideline (DCG) value for

${ }^{90} \mathrm{Sr}$ ] and alpha activity less than $2,500 \mathrm{dpm} /$ probe area (equivalent to $30 \mathrm{pCi} / \mathrm{L}$, the $\mathrm{DCG}$ value for ${ }^{239} \mathrm{Pu}$ ). Skin contamination in excess of these values will be decontaminated at the decontamination facility in the 325 Radiochemical Processing Laboratory or in the 329 Chemical Sciences Laboratory, where rinse water is retained in a holding tank.

The above activity limits were based on an evaluation performed on past skin contamination events that occurred from 1991 through 1996. Releases of beta/gamma activity and alpha activity were estimated and compared to the TEDF Waste Acceptance Criteria. Results indicated that skin contamination events within the above activity limits would not generate rinse water exceeding the DCGs found in DOE 5400.5, "Radiation Protection of the Public and the Environment." Based on this evaluation, skin decontamination events with the above activity limits are considered acceptable for the TEDF. 
This page intentionally left blank.

Issued: June 2000

PNNL-13276, Rev. 2

Supersedes: Rev. 1

Page 6 


\subsection{Facility-Specific Information}

The following data are provided in this section in accordance with RCP-310, 300 LEF Project Administration Procedures, Section 3.04, Liquid Waste Certification Program, Subsection 4.3 "Liquid Waste Certification Plan Content":

- a brief, general description of each Pacific Northwest building that discharges liquid waste to the PS or RPS

- a description of the types of activities that generate the effluent

- information concerning effluent constituents and the source of this information

- estimates of flow rates

- rationale for connections to the RPS.

Discharge access points to the PS and RPS from Pacific Northwest facilities include sink and hood drains from a large number of laboratories, R\&D equipment cooling facility systems (e.g., air conditioning, vacuum systems), drinking fountains, shower and eye-wash stations, and floor drains and trenches. Facilities also are served by individual boilers that are managed under an independent contract with discharges covered under a separate Liquid Waste Certification Plan. In many facilities, discharges are collected in a sump that is periodically pumped into the 300 Area PS or RPS system.

In each section's facility-specific table, the potential constituents in the effluent stream are those detected during the sampling campaign conducted by Pacific Northwest's Effluent Management staff in 1994 and 1995. Data presented in these tables include the constituent, the number of times the constituent was detected, the number of samples collected, the range of the constituent, the average value, and the standard deviation.

The following constituents, which are listed in the TEDF Waste Acceptance Criteria (see Appendix C for current criteria), were not included in the Pacific Northwest initial effluent characterization:

- chlorodifluoromethane - Chlorodifluoromethane is a refrigerant and was used in the past as a degreasing agent, but is not commonly used in Pacific Northwest facilities.

- suspended solids - Visual inspection and process knowledge indic ated that Pacific Northwest facilities were not a significant source of suspended solids. The major contributors to the PS and RPS are cooling waters and sink drains, neither of which contains measurable quantities of suspended solids. 
- coliform - Coliform would only be present if sanitary waste fixtures were connected to the PS or RPS. The room-by-room drain inventories of the Pacific Northwest facilities did not reveal any such crossconnections. Discharge from cage washing equipment in the 331 Life Sciences Laboratory I was evaluated in May 1998 and found to contain no coliform.

- gamma energy analysis (GEA) and total radium - Due to the low gross alpha analytical results, total radium analyses were not performed on the Pacific Northwest characterization samples. Gross alpha measurements were below $15 \mathrm{pCi} / \mathrm{L}$ in all samples collected, except for several at the 3720 Environmental Sciences Laboratory. The highest gross alpha value for the 3720 Environmental Sciences Laboratory was $44 \mathrm{pCi} / \mathrm{L}$, and the average value for the 52 samples collected at that facility was $12 \mathrm{pCi} / \mathrm{L}$.

Due to the low gross beta analytical results, GEA analyses were not performed on the Pacific Northwest characterization samples. Gross beta measurements were less than $30 \mathrm{pCi} / \mathrm{L}$ in sample s collected from all facilities; therefore, GEA results in excess of the 9,000 pCi/L TEDF Waste Acceptance Criteria were not considered credible.

The $\mathrm{pH}$ data presented in the facility-specific tables were obtained from the 24-hour composite samples. These data were selected to avoid short-term fluctuations that are not significant to the TEDF. Mixing of the various facilities' effluent streams and residence time in both the waste collection sump and the TEDF Equalization Tank accommodate short-term fluctuations in $\mathrm{pH}$.

Most Pacific Northwest-operated facilities discharge effluents that are not directly related to an R\&D activity to the PS. For example, the major source of effluent from the 3730 Gamma Irradiation Facility is steam condensate from the building steam heating system. In these cases, process knowledge is the basis for the data, rather than characterization sampling.

Flow rate data for the Pacific Northwest facilities with dedicated sampling stations were obtained from the flow measuring equipment. For those facilities that do not have installed flow measuring equipment, the data provided are the estimates used in the 300 Area Process Sewer Piping Upgrade, Project L-070. ${ }^{\text {(a) }}$ For this project, Pacific Northwest provided estimates of a maximum flow rate for each facility based upon normal operations and upset conditions, a duration for the maximum flow rate, and a frequency at which the maximum flow rate would occur.

\subsection{W Materials Development Laboratory}

Mission and Activities: In the past, the 306W Materials Development Laboratory has been used for research programs involving metal processing and component fabrication, such as the U.S. Army's depleted uranium penetrator program and the USCAR initiative. The penetrator program involved the heat treatment, forming, and machining of depleted uranium bars into penetrator designs. The USCAR

(a) Attachment to letter from T. B. Veneziano to T. D. Chikalla, "Design Flowrates for Replacement 300 Area Process Sewer System,” Project L-070, dated September 23, 1994. 
initiative supported the research and development of lightweight metal-matrix composite materials and super-plastic aluminum material for major domestic automotive manufacturers. This work included advanced casting technology; test-specimen fabrication; material testing of the metal matrix composite material; and the heat treatment, machining, and testing of the super-plastic aluminum material. Some metal work and storage of bulk metal still occurs in the building, but a large portion of the building has been shut down. In addition to the residual metal work, the building is used for Pacific Northwest waste operations activities, including catalytic electrochemical oxidation (a waste treatment process); x-ray and low-level waste repackaging; redistribution of chemical inventories; and waste storage and treatment, shipping, and receiving.

Physical Description: The 306W Materials Development Laboratory is a two-story, steelframed structure containing about $36,000 \mathrm{ft}^{2}$ of floor space, including large high-clearance process areas for metal working and a two-story office addition. The building is served by the 300 Area PS and SNS; the SNS serves the restrooms and lunchrooms, and the PS serves process areas. The building is also equipped with a closed-loop cooling system. In the past, failure of this system has resulted in the triggering of singlepass cooling, causing large quantities of water to be discharged to the process sewer. However, this failure mode was corrected in 1996, eliminating the potential for this discharge.

Radiological Inventory: Radiological inventories in the 306W Materials Development Laboratory include large quantities of depleted uranium bulk metal alloy, smaller quantities of enriched uranium in the building exhaust as holdup from previous operations, and some sealed sources.

Chemical Inventory: A review of the Chemical Management System for the 306W Materials Development Laboratory indicated that acids, bases, organics, and metals may all be present in the building.

Effluent Characterization: Although the 306W Materials Development Laboratory does not have a liquid effluent sampling system, the PS from the building was sampled with a portable sampler during the sampling campaign conducted by Pacific Northwest's Effluent Management staff in 1994 and 1995 (Thompson et al. 1997). Table 2.1 provides a summary of the results of the sampling campaign. These results show generally low concentrations [parts per billion (ppb)] of pollutants, less than the TEDF Waste Acceptance Criteria.

Estimated flow rates from the $306 \mathrm{~W}$ Materials Development Laboratory are 5 gallons per minute (gpm) average. An estimated range of 5 to $20 \mathrm{gpm}$ was used as the design flow rate range that was provided in conjunction with the replacement 300 Area Process Sewer System, Project L-070. 
Table 2.1. Constituents Detected in the 306W Materials Development Laboratory PS Samples

\begin{tabular}{|c|c|c|c|c|}
\hline \multirow[b]{2}{*}{ Constituent } & \multirow[b]{2}{*}{ Frequency $^{(\mathbf{b})}$} & \multicolumn{3}{|c|}{ Concentration [microgram per liter $(\mu \mathrm{g} / \mathrm{L})]^{(\mathrm{a})}$} \\
\hline & & Range & Average & $\begin{array}{c}\text { Standard } \\
\text { Deviation }^{(\mathrm{c})}\end{array}$ \\
\hline \multicolumn{5}{|c|}{ General Chemical Parameters } \\
\hline Alkalinity & $7 / 7$ & $60,000-120,000$ & 83,000 & 25,000 \\
\hline $\begin{array}{l}\text { Chemical Oxygen } \\
\text { Demand }\end{array}$ & $7 / 7$ & $4,500-13,000$ & 9,000 & 2,800 \\
\hline Conductivity & $8 / 8$ & $170-320$ & 230 & 55 \\
\hline $\mathrm{PH}$ & $8 / 8$ & $6.2-8.3$ & 7.4 & 0.87 \\
\hline Total Carbon & $8 / 8$ & $18,000-30,000$ & 23,000 & 4,500 \\
\hline Total Dissolved Solids & $7 / 7$ & $100,000-180,000$ & 140,000 & 34,000 \\
\hline Total Organic Carbon & $8 / 8$ & $2,000-15,000$ & 4,600 & 4,300 \\
\hline \multicolumn{5}{|c|}{ Ammonia and Anions } \\
\hline Ammonia & $4 / 7$ & $40-100$ & 58 & 29 \\
\hline Chloride & $7 / 7$ & $4,700-12,000$ & 7,300 & 2,500 \\
\hline Fluoride & $6 / 7$ & $230-460$ & 350 & 100 \\
\hline Nitrate & $7 / 7$ & $1,500-14,000$ & 7,900 & 4,800 \\
\hline Sulfate & $7 / 7$ & $13,000-23,000$ & 17,000 & 2,900 \\
\hline Sulfides & $3 / 7$ & $220-300$ & 270 & 46 \\
\hline \multicolumn{5}{|c|}{ Metals } \\
\hline Aluminum & $6 / 8$ & $33-190$ & 74 & 60 \\
\hline Arsenic & $1 / 8$ & - & 2.8 & - \\
\hline Barium & $8 / 8$ & $26-43$ & 34 & 5 \\
\hline Beryllium & $1 / 8$ & - & 0.19 & - \\
\hline Calcium & $8 / 8$ & $22,000-41,000$ & 30,000 & 6,800 \\
\hline Chromium & $1 / 8$ & - & 5.0 & - \\
\hline Copper & $8 / 8$ & $9.4-56$ & 20 & 17 \\
\hline Iron & $8 / 8$ & $160-910$ & 350 & 320 \\
\hline Lead & $3 / 8$ & $3.2-7.2$ & 5.4 & 2.0 \\
\hline Magnesium & $8 / 8$ & $4,800-8,800$ & 6,500 & 1,400 \\
\hline Manganese & $8 / 8$ & $7.2-27$ & 16 & 6.4 \\
\hline Mercury & $2 / 8$ & $0.083-0.084$ & 0.084 & - \\
\hline Potassium & $8 / 8$ & $1,200-3,100$ & 1,900 & 710 \\
\hline Selenium & $1 / 8$ & - & 0.73 & - \\
\hline Silver & $1 / 8$ & - & 3.6 & - \\
\hline Sodium & $8 / 8$ & $3,400-11,000$ & 6,300 & 2,600 \\
\hline Thallium & $1 / 8$ & - & 0.88 & - \\
\hline Zinc & $8 / 8$ & $66-280$ & 110 & 77 \\
\hline
\end{tabular}


Table 2.1. (contd)

\begin{tabular}{|c|c|c|c|c|}
\hline \multirow[b]{2}{*}{ Constituent } & \multirow[b]{2}{*}{ Frequency $^{(\mathbf{b})}$} & \multicolumn{3}{|c|}{ Concentration [microgram per liter $(\mu \mathrm{g} / \mathrm{L})]^{(\mathrm{a})}$} \\
\hline & & Range & Average & $\begin{array}{c}\text { Standard } \\
\text { Deviation }^{(\mathrm{c})}\end{array}$ \\
\hline \multicolumn{5}{|c|}{ Volatile Organic Compounds } \\
\hline Acetone & $2 / 9$ & $14-15$ & 15 & - \\
\hline Bromoform & $1 / 9$ & - & 2.0 & - \\
\hline Chloroform & $8 / 9$ & $0.9-1.8$ & 1.4 & 0.3 \\
\hline Methylene Chloride & $2 / 9$ & $1.1-1.2$ & 1.1 & - \\
\hline \multicolumn{5}{|c|}{ Radiological Parameters } \\
\hline Gross Alpha & $8 / 8$ & $0.93-6.4$ & 3.5 & 0.56 \\
\hline Gross Beta & $6 / 8$ & $2.4-20$ & 7.0 & 2.7 \\
\hline Tritium & $3 / 8$ & $290-690$ & 430 & 130 \\
\hline \multicolumn{5}{|c|}{$\begin{array}{l}\text { (a) Number of samples with detectable concentrations/total number of samples analyzed. } \\
\text { (b) Conductivity units are } \mu \text { mhos/cm (a mho is the inverse of an ohm and has units of amperes/volts) } \\
\text { and radiological parameters are pCi/L. } \\
\text { (c) Two times the standard error of the mean for radiological parameters. }\end{array}$} \\
\hline
\end{tabular}

\subsection{Radiological Calibrations Laboratory}

Mission and Activities: The 318 Radiological Calibrations Laboratory is primarily used to provide technical services in internal dosimetry; external dosimetry; and instrument calibration, repair, and testing for 1) protecting the health of workers and the public and 2) providing liability protection for government and industrial customers. Research in the building includes development of radiation detection and measuring instruments.

Physical Description: The 318 Radiological Calibrations Laboratory contains about $37,000 \mathrm{ft}^{2}$ of floor space in a two-story building with a basement. The basement area contains an x-ray room and control room, a high-exposure room, and a mechanical equipment room. The first floor contains a low-scatter room, laboratories, and a small computer room. The second floor contains offices, a lunchroom, and a mechanical equipment room.

The 318 Radiological Calibrations Laboratory is served by the 300 Area PS and SNS; the SNS serves the restrooms and lunchrooms, and the PS serves process areas. The facility does not have an installed liquid effluent sampling system.

Radiological Inventory: Most of the radiological inventory in the 318 Radiological Calibrations Laboratory is in the form of sealed sources, although very small quantities of radon and thoron gases are emitted during some calibrations. Also, microcurie or less quantities of various radioactive materials may also be present in the form of check sources, dispersible solids, or liquids. 
Chemical Inventory: A review of the Chemical Management System for the 318 Radiological Calibrations Laboratory indicated that acids, bases, organics, and inorganics may all be present in the building.

Effluent Characterization: Liquid effluents from the 318 Radiological Calibrations Laboratory have not been sampled. With few dispersible radioactive materials and minor quantities of hazardous chemicals, the potential for effluent release to the PS or SNS is considered low.

The 318 Radiological Calibrations Laboratory does not possess flow rate measuring equipment; therefore, flow rate estimates are the design flow rates that were provided in conjunction with Project L-070, the replacement 300 Area Process Sewer System. These are approximately an average of $12 \mathrm{gpm}$ with a range of 2 to $62 \mathrm{gpm}$. Cooling water for the x-ray machine requires about $2 \mathrm{gpm}$ continuous flow and the estimated maximum flow rate is based on a number of sinks being used simultaneously. Estimates of current actual flow rates are 2-8 gpm monthly average.

\subsection{Analytical and Nuclear Research Laboratory}

Mission and Activities: Research activities conducted in the 320 Analytical and Nuclear Research Laboratory involve special-purpose separation and analytical chemistry techniques that allow measurement of low-level and ultra-trace levels of material in environmental samples. Working with samples containing low/trace levels requires special building features, such as a clean zone. A class 10000 clean zone allows for contamination-free preparation and analysis of samples containing extremely low levels of indicator radionuclides and trace organic compounds. Special instruments that are used for sample analysis include various mass spectrometers, electron-beam microscopes, $\mathrm{x}$-ray diffraction, and radiation counters.

Physical Description: The 320 Analytical and Nuclear Research Laboratory consists primarily of two floors: one ground-level floor and a basement. A self-contained addition was added that consists of four labs and eight offices attached at both levels to the west end of the older building. Three small equipment rooms are located in the new addition, with one large equipment room in the older portion occupying the southeast corner of the basement. Half of the older portion ground-level laboratory space is "clean zone" modular rooms with high-efficiency particulate air- (HEPA-) filtered supply air. The building contains about 31,000 total $\mathrm{ft}^{2}$ of floor space.

The 320 Analytical and Nuclear Research Laboratory is served by the 300 Area PS and SNS; the SNS serves the restrooms and lunchrooms, and the PS serves process areas. The building is equipped with a liquid effluent sampling system on the west discharge line of the PS that includes capability for continuously monitoring $\mathrm{pH}$, conductivity, and flow, as well as capability for obtaining flow-composite samples.

Radiological Inventory: The 320 Analytical and Nuclear Research Laboratory contains small quantities (millicuries or less) of radioactive materials in various forms. 
Chemical Inventory: A review of the Chemical Management System for the 320 Analytical and Nuclear Research Laboratory indicated that acids, bases, organics, and inorganics may all be present in the building.

Effluent Characterization: The 320 Analytical and Nuclear Research Laboratory is equipped with a liquid effluent sampling system for the PS discharges from the west side of the building. Sampling was performed from this line during the sampling campaign conducted by Pacific Northwest's Effluent Management staff in 1994 and 1995 (Thompson et al. 1997). Table 2.2 provides a summary of the results of the sampling campaign. These results show generally low concentrations (ppb - parts per billion) of pollutants, less than the TEDF Waste Acceptance Criteria.

The 320 Analytical and Nuclear Research Laboratory has two discharge lines from the building. Discharge flows from the west discharge line have been measured and average 1 to $5 \mathrm{gpm}$, most of which is cooling water. Flows from the east discharge line are estimated at about $20 \mathrm{gpm}$. Maximum potential flow rates from the east and west discharge lines are estimated at 50 and 75 gpm, respectively, based on pumping abilities from the sump. Estimated frequencies and duration are once per hour and 5 minutes, respectively.

Table 2.2. Constituents Detected in the 320 Analytical and Nuclear Research Laboratory PS Samples

\begin{tabular}{|c|c|c|c|c|}
\hline \multirow[b]{2}{*}{ Constituent } & \multirow[b]{2}{*}{ Frequency $^{(\mathbf{b})}$} & \multicolumn{3}{|c|}{ Concentration $(\mu \mathrm{g} / \mathrm{L})]^{(\mathrm{a})}$} \\
\hline & & Range & Average & $\begin{array}{c}\text { Standard } \\
\text { Deviation }^{(\mathrm{c})}\end{array}$ \\
\hline \multicolumn{5}{|c|}{ General Chemical Parameters } \\
\hline Alkalinity & $38 / 38$ & $6,000-130,000$ & 58,000 & 20,000 \\
\hline $\begin{array}{l}\text { Chemical Oxygen } \\
\text { Demand }\end{array}$ & $9 / 38$ & $2,600-13,000$ & 6,300 & 3,400 \\
\hline Conductivity & $31 / 31$ & $58-940$ & 200 & 180 \\
\hline $\mathrm{PH}$ & $31 / 31$ & $5.5-10$ & 7.9 & 0.8 \\
\hline Total Carbon & $38 / 38$ & $11,000-31,000$ & 16,000 & 4,000 \\
\hline Total Dissolved Solids & $38 / 38$ & $70,000-210,000$ & 100,000 & 31,000 \\
\hline Total Organic Carbon & $39 / 39$ & $1,000-3,000$ & 1,800 & 630 \\
\hline \multicolumn{5}{|c|}{ Ammonia and Anions } \\
\hline Ammonia & $4 / 43$ & $30-40$ & 33 & 5 \\
\hline Chloride & $41 / 41$ & $2,100-12,000$ & 4,700 & 1,800 \\
\hline Cyanide & $2 / 39$ & $2-20$ & 11 & - \\
\hline Fluoride & $38 / 41$ & $230-700$ & 480 & 130 \\
\hline Nitrate & $41 / 41$ & $100-16,000$ & 1,700 & 3,200 \\
\hline Sulfate & $41 / 41$ & $10,000-24,000$ & 16,000 & 2,200 \\
\hline Sulfides & $9 / 38$ & $220-400$ & 300 & 50 \\
\hline
\end{tabular}


Table 2.2. (contd)

\begin{tabular}{|c|c|c|c|c|}
\hline \multirow[b]{2}{*}{ Constituent } & \multirow[b]{2}{*}{ Frequency $^{(\mathbf{b})}$} & \multicolumn{3}{|c|}{ Concentration [microgram per liter $(\mu \mathrm{g} / \mathrm{L})]^{(\mathrm{a})}$} \\
\hline & & Range & Average & $\begin{array}{c}\text { Standard } \\
\text { Deviation }^{(\mathrm{c})}\end{array}$ \\
\hline \multicolumn{5}{|c|}{ Metals } \\
\hline Aluminum & $39 / 43$ & $29-170$ & 66 & 34 \\
\hline Antimony & $2 / 43$ & $37-39$ & 38 & - \\
\hline Arsenic & $1 / 39$ & - & 0.73 & - \\
\hline Barium & $43 / 43$ & $16-46$ & 29 & 5 \\
\hline Beryllium & $5 / 43$ & $0.17-0.68$ & 0.34 & 0.21 \\
\hline Cadmium & $2 / 43$ & $3.5-4.3$ & 3.9 & - \\
\hline Calcium & $43 / 43$ & $16,000-44,000$ & 21,000 & 5,500 \\
\hline Chromium & $5 / 43$ & $5.7-18$ & 11 & 5 \\
\hline Cobalt & $2 / 43$ & $7.5-7.6$ & 7.5 & - \\
\hline Copper & $40 / 43$ & $2.9-13$ & 6.8 & 2.3 \\
\hline Iron & $37 / 43$ & $8.7-170$ & 36 & 29 \\
\hline Lead & $21 / 39$ & $0.6-15$ & 2.1 & 3.1 \\
\hline Magnesium & $43 / 43$ & $3,600-9,300$ & 4,800 & 1,100 \\
\hline Manganese & $29 / 43$ & $0.89-7.1$ & 1.5 & 1.2 \\
\hline Mercury & $8 / 39$ & $0.052-0.46$ & 0.15 & 0.13 \\
\hline Nickel & $2 / 43$ & $13-16$ & 15 & - \\
\hline Potassium & $28 / 43$ & $860-2,900$ & 1,400 & 480 \\
\hline Selenium & $8 / 43$ & $0.66-2.3$ & 1.1 & 0.60 \\
\hline Silicon & $1 / 1$ & - & 2,800 & - \\
\hline Sodium & $43 / 43$ & $2,300-11,000$ & 3,400 & 1,800 \\
\hline Strontium & $2 / 2$ & $92-100$ & 96 & - \\
\hline Thallium & $7 / 39$ & $0.62-1.6$ & 0.85 & 0.37 \\
\hline Tin & $4 / 43$ & $26-82$ & 46 & 25 \\
\hline Vanadium & $2 / 43$ & $3.3-3.5$ & 3.4 & - \\
\hline Zinc & $43 / 43$ & $11-120$ & 29 & 18 \\
\hline \multicolumn{5}{|c|}{ Volatile Organic Compounds } \\
\hline 1,1,1-Trichloroethane & $3 / 62$ & $1.2-2.6$ & 1.8 & 0.7 \\
\hline 2-Butanone & $1 / 62$ & - & 26 & - \\
\hline Acetone & $5 / 62$ & $8.8-43$ & 26 & 13 \\
\hline Acetonitrile & $1 / 27$ & - & 170 & - \\
\hline Bromodichloromethane & $25 / 36$ & $0.7-3.3$ & 1.6 & 0.7 \\
\hline Bromoform & $1 / 36$ & - & 0.5 & - \\
\hline Chloroform & $62 / 62$ & $6.9-32$ & 19 & 6.6 \\
\hline Dibromochloromethane & $3 / 36$ & $1.4-2.0$ & 1.8 & 0.3 \\
\hline Ethylbenzene & $4 / 36$ & $0.5-4.9$ & 1.7 & 2.1 \\
\hline
\end{tabular}


Table 2.2. (contd)

\begin{tabular}{|c|c|c|c|c|}
\hline \multirow[b]{2}{*}{ Constituent } & \multirow[b]{2}{*}{ Frequency $^{(\mathbf{b})}$} & \multicolumn{3}{|c|}{ Concentration [microgram per liter $(\mu \mathrm{g} / \mathrm{L})]^{(\mathrm{a})}$} \\
\hline & & Range & Average & $\begin{array}{c}\text { Standard } \\
\text { Deviation }^{(\mathrm{c})}\end{array}$ \\
\hline \multicolumn{5}{|c|}{ Volatile Organic Compounds (contd) } \\
\hline Hexone & $6 / 62$ & $1.4-110$ & 37 & 41 \\
\hline Methylene chloride & $40 / 62$ & $0.4-1.6$ & 1.1 & 0.4 \\
\hline Tetrahydrofuran & $1 / 62$ & - & 36 & - \\
\hline Toluene & $2 / 62$ & $0.14-0.18$ & 0.16 & - \\
\hline Xylenes (total) & $8 / 62$ & $0.48-12$ & 4.8 & 4.6 \\
\hline \multicolumn{5}{|c|}{ Semivolatile Organic Compounds (Acids/Bases/Neutrals) } \\
\hline Di-n-butylphthalate & $2 / 14$ & $2.5-2.6$ & 2.5 & - \\
\hline Phenol & $1 / 43$ & - & 1.8 & - \\
\hline \multicolumn{5}{|c|}{ Radiological Parameters } \\
\hline Gross Alpha & $8 / 43$ & $0.87-2.9$ & 1.7 & 0.26 \\
\hline Gross Beta & $11 / 43$ & $2.1-4.3$ & 3.2 & 0.2 \\
\hline \multicolumn{5}{|c|}{$\begin{array}{l}\text { (a) Number of samples with detectable concentrations/total number of samples analyzed. } \\
\text { (b) Conductivity units are } \mu \mathrm{mhos} / \mathrm{cm} \text { and radiological parameters are } \mathrm{pCi} / \mathrm{L} \text {. } \\
\text { (c) Two times the standard error of the mean for radiological parameters. }\end{array}$} \\
\hline
\end{tabular}

\subsection{Mechanical Properties Laboratory}

Mission and Activities: Work in the 323 Mechanical Properties Laboratory includes research into the development and characterization of structural materials. The activities conducted in this building are in support of the mechanical property (tensile and compression) testing mission for both radioactive and nonradioactive material as well as autoclave testing for high-temperature corrosion and stress corrosion studies. Tests are conducted in a small hot cell. Tested materials are solid form and contain activation products resulting from irradiation in a reactor.

Physical Description: The 323 Mechanical Properties Laboratory is a one-story, rectangular-shaped, metal frame structure built on a concrete foundation and floor slab. The roof is pitched, and the exterior of the building is made of insulated metal siding. The building contains about 4,200 $\mathrm{ft}^{2}$ of floor space. The building is serviced by the 300 Area SNS and PS and is not equipped with any liquid effluent sampling or monitoring systems.

Radiological Inventory: In the 323 Mechanical Properties Laboratory, small samples of activated reactor structural components are tested in the hot cell. Radioactivity present is contained within a metal matrix and is not dispersible.

Chemical Inventory: A review of the Chemical Management System for the 323 Mechanical Properties Laboratory indicated that acids, bases, organics, and inorganics may all be present in the building. 
Effluent Characterization: The only work being performed in the 323 Mechanical Properties Laboratory involves the hot cell. Liquid wastes are not generated during these operations; therefore, no effluent sampling or monitoring has been performed. The major source of effluent from this building is storm water. Effluent from this building discharges to a sump equipped with two pumps that are floatswitch-controlled. The sump is estimated to discharge about once per week for 5 minutes with an estimated average daily flow rate of $1 \mathrm{gpm}$.

\subsection{Radiochemical Processing Laboratory}

Mission and Activities: The 325 Radiochemical Processing Laboratory houses radiochemistry research, radioanalytical services, radiochemical process development, and mixed waste treatment activities. The laboratories and specialized facilities enable work ranging from that with nonradioactive materials to work with picogram to kilogram quantities of fissionable materials and up to megacurie quantities of other radionuclides. The special facilities include 1) two shielded hot cell areas that provide for process development or analytical chemistry work with highly radioactive materials, and 2) a waste treatment unit for processing mixed, low-level, and transuranic wastes generated by Pacific Northwest activities. The office, laboratory, and shop space house staff from Pacific Northwest's research divisions and support services (maintenance staff, power operators, radiological control technicians, and building management).

Physical Description: The 325 Radiochemical Processing Laboratory is a 3-story, welded metal frame structure with insulated metal siding erected on reinforced concrete footings, walls, and slabs. The building contains about $144,000 \mathrm{ft}^{2}$ of floor space, of which a third is laboratory space. The building consists of

- a central portion containing general purpose laboratories designed for general chemical and low-level radiochemical work

- a south (front) wing containing office space, a machine and electrical shop, locker rooms, and a lunchroom

- east and west wings provided with shielded enclosures with remote manipulators for high-level radiochemical work

- a filter addition area that provides a final testable HEPA filtration stage for ventilation exhaust air

- an outside radioactive materials storage area and cargo containers.

The first floor of the building contains approximately 100 laboratories and offices; the laboratories contain numerous fume hoods and gloveboxes for working safely with radioactive and hazardous materials. Offices are also located on the second floor and on a mezzanine area between the first floor and the basement. The basement contains several laboratories in addition to a portion of the ventilation and waste-handling systems. Instrument rooms, certain isolated laboratories, and the basement mezzanine office area have refrigerated air conditioning for temperature and humidity control. 
The 325 Radiochemical Processing Laboratory is served by the 300 Area RPS and SNS. The SNS serves the restrooms and lunchrooms, and the RPS serves the process areas. The PS system formerly used in the building was converted to an RPS system in the early 1990s because of the potential for radioactive contamination. The building is equipped with a liquid effluent sampling system on the RPS that includes the capability for continuously monitoring $\mathrm{pH}$, conductivity, and flow, as well as the capability for obtaining flow-composite samples. In addition, the building is connected to the RLWS for disposing radioactive liquid waste. This system does not contribute to the PS or RPS systems.

Radiological Inventory: The laboratories and specialized facilities in the 325 Radiochemical Processing Laboratory enable work with picogram to kilogram quantities of fissionable materials and up to megacurie quantities of other radionuclides. Radioactive materials present include fission and activation products, tritium, plutonium, and uranium.

Chemical Inventory: Chemical storage and usage are dispersed throughout the 325 Radiochemical Processing Laboratory and consist of bulk materials, small volume chemicals, and standards used in conducting laboratory analyses and experiments. Almost all classes of chemicals may be present including acids, bases, organics, and inorganics.

Effluent Characterization: The 325 Radiochemical Processing Laboratory is equipped with a liquid effluent sampling system for the RPS and was sampled during the sampling campaign conducted by Pacific Northwest's Effluent Management staff in 1994 and 1995 (Thompson et al. 1997). Table 2.3 provides a summary of the results of the sampling campaign and lists the average concentrations from samples taken from normal work days. These results show low concentrations (ppb) of pollutants, generally less than the TEDF Waste Acceptance Criteria.

RPS flow rates have been measured and the monthly averages range from less than 1 to $3 \mathrm{gpm}$. Maximum flows from the sump may be up to $50 \mathrm{gpm}$.

\subsection{Materials Sciences Laboratory}

Mission and Activities: The 326 Materials Sciences Laboratory is used to conduct mechanical testing of metallic and ceramic composite materials, specimen preparation for optical/electron beam microscopes and the subsequent examination/characterization of these specimens, and the preparation of specimens for $\mathrm{X}$-ray diffraction analysis. Sample preparation activities include sample receiving and sample size reduction (cutting, grinding, punching, breaking, electropolishing, and ion micromilling). In addition, analytical characterization of samples from the radioactive waste tank is performed.

Physical Description: The 326 Materials Sciences Laboratory is a two-story building with a basement. The framework is bolted-steel and exterior walls are fluted steel insulated panels. Floors are reinforced concrete finished with vinyl asbestos tile with access trenches for utility distribution under the main floor. The building contains about $63,000 \mathrm{ft}^{2}$ of floor space and is equipped with gloveboxes, fume hoods, and hot cells. 
Table 2.3. Constituents Detected in 325 Radiochemical Processing Laboratory RPS Samples

\begin{tabular}{|c|c|c|c|}
\hline \multicolumn{4}{|c|}{ General Chemical Parameter $(\boldsymbol{\mu g} / \mathrm{L})$} \\
\hline Alkalinity & 43,400 & Total Carbon & 22,250 \\
\hline $\begin{array}{l}\text { Chemical Oxygen } \\
\text { Demand }\end{array}$ & 42,333 & Total Dissolved Solids & 82,000 \\
\hline Conductivity & $155(\mu \mathrm{mhos} / \mathrm{sm})$ & Total Organic Carbon & 4,850 \\
\hline $\mathrm{pH}$ & 7.55 (pH units) & & \\
\hline \multicolumn{4}{|c|}{ Ammonia and Anions $(\mu \mathrm{g} / \mathrm{L})$} \\
\hline Ammonia & 70 & Nitrate & 28,983 \\
\hline Chloride & 3,937 & Nitrite & 300 \\
\hline Cyanide & 2.0 & Sulfate & 15,383 \\
\hline Fluoride & 432 & & \\
\hline \multicolumn{4}{|c|}{ Metals $(\mu \mathrm{g} / \mathrm{L})$} \\
\hline Aluminum & 78 & Potassium & 946 \\
\hline Barium & 25 & Selenium & 1.02 \\
\hline Calcium & 17,800 & Silicon & 2,650 \\
\hline Chromium & 5.6 & Sodium & 3,473 \\
\hline Copper & 17.2 & Strontium & 98 \\
\hline Iron & 186 & Thallium & 1.00 \\
\hline Lead & 3.8 & Tin & 33 \\
\hline Magnesium & 4,220 & Vanadium & 2.6 \\
\hline Manganese & 5.1 & Zinc & 72 \\
\hline Mercury & 1.167 & & \\
\hline \multicolumn{4}{|c|}{ Volatile Organic Compounds $(\mu \mathrm{g} / \mathrm{L})$} \\
\hline 1,4-Dichlorobenzene & 1.1 & Ethanol & 6.1 \\
\hline Acetone & 45.07 & Hexone & 18.4 \\
\hline Chloroform & 9.6 & & \\
\hline \multicolumn{4}{|c|}{ Semi-volatile Organic Compounds $(\mu \mathrm{g} / \mathrm{L})$} \\
\hline 1,4-Dichlorobenzene & 1.1 & Phenol & 2.6 \\
\hline Bis(2-ethylhexyl)phthalate & 15 & Tributyl Phosphate & 0.84 \\
\hline \multicolumn{4}{|c|}{ Radiological Parameters (pCi/L) } \\
\hline Gross Alpha & 4.922 & Tritium & 318 \\
\hline
\end{tabular}

The 326 Materials Sciences Laboratory is served by the 300 Area PS, RPS, and SNS. The SNS serves the restrooms and lunchrooms, the PS serves process areas, and the RPS serves process areas that have a greater potential to discharge radioactive materials. The building is equipped with a liquid effluent sampling system on the PS and RPS that includes the capability for continuously monitoring $\mathrm{pH}$, conductivity, and flow, as well as the capability for obtaining flow-composite samples. An RLWS that has served the building in the past has been disconnected. 
Radiological Inventory: Radioactive material in the 326 Materials Sciences Laboratory is primarily from samples that may be in the form of solid, powder, fragments, and monoliths. The materials include solid samples containing activation products resulting from irradiation in reactors and spent fuel powders/fragments. A wide range of radionuclides may be present.

Chemical Inventory: A review of the Chemical Management System for the 326 Materials Sciences Laboratory indicated that acids, bases, organics, and inorganics may all be present within the building.

Effluent Characterization: The 326 Materials Sciences Laboratory is equipped with liquid effluent sampling systems for both the PS and RPS and was sampled during the sampling campaign conducted by Pacific Northwest's Effluent Management staff in 1994 and 1995 (Thompson et al. 1997). Tables 2.4 and 2.5 provide a summary of the results of the sampling campaign for the PS and RPS, respectively. These results show low concentrations ( $\mathrm{ppb}$ ) of pollutants, generally less than the TEDF Waste Acceptance Criteria.

Liquid effluent flow rates from the 326 Materials Sciences Laboratory are low. Measured discharges from the PS have monthly averages ranging from 0.2 to $5.6 \mathrm{gpm}$. Measured discharges from the RPS range from monthly averages of 0.1 to $0.5 \mathrm{gpm}$. Maximum flows are estimated at $20 \mathrm{gpm}$ for the PS and 30 gpm for the RPS.

Table 2.4. Constituents Detected in the 326 Materials Sciences Laboratory PS Samples

\begin{tabular}{|c|c|c|c|c|}
\hline \multirow[b]{2}{*}{ Constituent } & \multirow[b]{2}{*}{ Frequency $^{(\mathbf{b})}$} & \multicolumn{3}{|c|}{ Concentration $(\mu \mathrm{g} / \mathrm{L})]^{(\mathrm{a})}$} \\
\hline & & Range & Average & $\begin{array}{c}\text { Standard } \\
\text { Deviation }^{(\mathrm{c})}\end{array}$ \\
\hline \multicolumn{5}{|c|}{ General Chemical Parameters } \\
\hline Alkalinity & $13 / 13$ & $20,000-130,000$ & 71,000 & 33,000 \\
\hline $\begin{array}{l}\text { Chemical Oxygen } \\
\text { Demand }\end{array}$ & $12 / 13$ & $4,000-360,000$ & 50,000 & 100,000 \\
\hline Conductivity & $23 / 23$ & $98-350$ & 200 & 71 \\
\hline $\mathrm{pH}$ & $23 / 23$ & $1.8-8.9$ & 7.3 & 1.5 \\
\hline Total carbon & $13 / 13$ & $13,000-120,000$ & 31,000 & 29,000 \\
\hline Total Dissolved Solids & $13 / 13$ & $80,000-210,000$ & 130,000 & 49,000 \\
\hline Total Organic Carbon & $20 / 20$ & $2,000-110,000$ & 11,000 & 24,000 \\
\hline \multicolumn{5}{|c|}{ Ammonia and Anions } \\
\hline Ammonia & $14 / 24$ & $40-500$ & 190 & 140 \\
\hline Chloride & $21 / 21$ & $2,900-85,000$ & 9,500 & 17,000 \\
\hline Fluoride & $21 / 21$ & $270-600$ & 400 & 98 \\
\hline Nitrate & $21 / 21$ & $400-12,000$ & 3,500 & 3,600 \\
\hline Nitrite & $3 / 12$ & - & 200 & - \\
\hline Phosphate & $1 / 21$ & - & 1,100 & - \\
\hline
\end{tabular}


Table 2.4. (contd)

\begin{tabular}{|c|c|c|c|c|}
\hline \multirow[b]{2}{*}{ Constituent } & \multirow[b]{2}{*}{ Frequency $^{(\mathbf{b})}$} & \multicolumn{3}{|c|}{ Concentration $(\mu \mathrm{g} / \mathrm{L})]^{(\mathrm{a})}$} \\
\hline & & Range & Average & $\begin{array}{c}\text { Standard } \\
\text { Deviation }^{(\mathrm{c})}\end{array}$ \\
\hline \multicolumn{5}{|c|}{ Ammonia and Anions (contd) } \\
\hline Sulfate & $21 / 21$ & $13,000-53,000$ & 23,000 & 12,000 \\
\hline Sulfides & $3 / 13$ & $220-400$ & 300 & 90 \\
\hline \multicolumn{5}{|c|}{ Metals } \\
\hline Aluminum & $19 / 24$ & $29-180$ & 64 & 38 \\
\hline Barium & $24 / 24$ & $21-100$ & 33 & 17 \\
\hline Beryllium & $4 / 24$ & $0.19-0.26$ & 0.21 & 0.03 \\
\hline Cadmium & $6 / 24$ & $1-14$ & 4.2 & 5.0 \\
\hline Calcium & $24 / 24$ & $14,000-43,000$ & 24,000 & 8,000 \\
\hline Chromium & $8 / 24$ & $3.7-7.7$ & 5.5 & 1.3 \\
\hline Cobalt & $1 / 24$ & - & 8.4 & - \\
\hline Copper & $24 / 24$ & $31-1,400$ & 160 & 300 \\
\hline Iron & $24 / 24$ & $23-6,000$ & 480 & 1,200 \\
\hline Lead & $14 / 20$ & $1.5-8.6$ & 3.4 & 2.3 \\
\hline Magnesium & $24 / 24$ & $2,400-9,100$ & 5,100 & 1,600 \\
\hline Manganese & $24 / 24$ & $2.2-1,500$ & 96 & 300 \\
\hline Mercury & $5 / 20$ & $0.026-0.23$ & 0.11 & 0.075 \\
\hline Nickel & $5 / 24$ & $14-340$ & 89 & 140 \\
\hline Potassium & $22 / 24$ & $840-3,900$ & 1,700 & 910 \\
\hline Selenium & $3 / 24$ & $0.73-1.2$ & 1.0 & 0.27 \\
\hline Silicon & $3 / 23$ & $2,200-2,600$ & 2,500 & 230 \\
\hline Sodium & $24 / 24$ & $2,600-24,000$ & 6,500 & 5,100 \\
\hline Strontium & $5 / 5$ & $90-100$ & 94 & 5 \\
\hline Thallium & $5 / 20$ & $0.93-2.9$ & 1.5 & 0.80 \\
\hline Tin & $2 / 24$ & $34-49$ & 42 & - \\
\hline Vanadium & $6 / 24$ & $2-4$ & 2.5 & 0.8 \\
\hline Zinc & $24 / 24$ & $48-6,100$ & 470 & 1,300 \\
\hline \multicolumn{5}{|c|}{ Volatile Organic Compounds } \\
\hline 2-Butanone & $1 / 22$ & - & 48 & - \\
\hline Acetone & $20 / 22$ & $5.5-2,500$ & 280 & 560 \\
\hline Chloroform & $19 / 22$ & $0.6-4.3$ & 1.7 & 0.9 \\
\hline Hexone & $2 / 22$ & $1.7-2.0$ & 1.9 & - \\
\hline Isopropyl alcohol & $1 / 22$ & - & 41,000 & - \\
\hline Methylene Chloride & $2 / 22$ & - & 1.2 & - \\
\hline
\end{tabular}


Table 2.4. (contd)

\begin{tabular}{|c|c|c|c|c|}
\hline \multirow[b]{2}{*}{ Constituent } & \multirow[b]{2}{*}{ Frequency $^{(\mathbf{b})}$} & \multicolumn{3}{|c|}{ Concentration $(\mu \mathrm{g} / \mathrm{L})]^{(\mathrm{a})}$} \\
\hline & & Range & Average & $\begin{array}{c}\text { Standard } \\
\text { Deviation }^{(\mathrm{c})}\end{array}$ \\
\hline \multicolumn{5}{|c|}{ Volatile Organic Compounds (contd) } \\
\hline Tetrachloroethene & $1 / 22$ & - & 0.51 & - \\
\hline Tetrahydrofuran & $17 / 22$ & $2.8-22$ & 10.4 & 6.5 \\
\hline Trichloroethene & $3 / 22$ & $0.95-5.9$ & 2.9 & 2.6 \\
\hline \multicolumn{5}{|c|}{ Semivolatile Organic Compounds (Acids/Bases/Neutrals) } \\
\hline $\begin{array}{l}\text { Bis(2-ethylhexyl) } \\
\text { phthalate }\end{array}$ & $2 / 24$ & $0.88-1.7$ & 1.29 & - \\
\hline Di-n-octylphthalate & $1 / 6$ & - & 1.3 & - \\
\hline Diethylphthalate & $1 / 6$ & - & 6.6 & - \\
\hline Phenol & $4 / 24$ & $0.83-3.7$ & 1.8 & 1.3 \\
\hline \multicolumn{5}{|c|}{ Semivolatile Organic Compounds (Pesticides) } \\
\hline Aldrin & $1 / 9$ & - & 0.0041 & - \\
\hline Alpha-BHC & $2 / 9$ & $0.0011-0.0025$ & 0.0018 & - \\
\hline Delta-BHC & $1 / 9$ & - & 0.0041 & - \\
\hline \multicolumn{5}{|c|}{ Radiological Parameters } \\
\hline Gross Alpha & $3 / 24$ & $1.2-1.7$ & 1.4 & 0.14 \\
\hline Gross Beta & $8 / 24$ & $2.4-7.9$ & 5.0 & 0.73 \\
\hline Tritium & $7 / 24$ & $250-560$ & 380 & 38 \\
\hline \multicolumn{5}{|c|}{$\begin{array}{l}\text { (a) Number of samples with detectable concentrations/total number of samples analyzed. } \\
\text { (b) Conductivity units are } \mu \text { mhos } / \mathrm{cm} \text { and radiological parameters are } \mathrm{pCi} / \mathrm{L} \text {. } \\
\text { (c) Two times the standard error of the mean for radiological parameters. }\end{array}$} \\
\hline
\end{tabular}

Table 2.5. Constituents Detected in the 326 Materials Sciences Laboratory RPS Samples

\begin{tabular}{|c|c|c|c|c|}
\hline \multirow[b]{2}{*}{ Constituent } & \multirow[b]{2}{*}{ Frequency $^{(\mathbf{b})}$} & \multicolumn{3}{|c|}{ Concentration $(\mu \mathrm{g} / \mathrm{L})]^{(\mathbf{a})}$} \\
\hline & & Range & Average & $\begin{array}{c}\text { Standard } \\
\text { Deviation }^{(\mathrm{c})}\end{array}$ \\
\hline \multicolumn{5}{|c|}{ General Chemical Parameters } \\
\hline Conductivity & $2 / 2$ & $191-200$ & 200 & - \\
\hline $\mathrm{pH}$ & $2 / 2$ & $7.7-8$ & 7.9 & - \\
\hline Total Organic Carbon & $2 / 2$ & $3,000-20,000$ & 12,000 & - \\
\hline \multicolumn{5}{|c|}{ Ammonia and Anions } \\
\hline Ammonia & $1 / 2$ & - & 40 & - \\
\hline Bromide & $1 / 2$ & - & 40 & - \\
\hline Chloride & $2 / 2$ & $3,100-3,800$ & 3,500 & - \\
\hline
\end{tabular}


Table 2.5. (contd)

\begin{tabular}{|c|c|c|c|c|}
\hline \multirow[b]{2}{*}{ Constituent } & \multirow[b]{2}{*}{ Frequency $^{(\mathbf{b})}$} & \multicolumn{3}{|c|}{ Concentration $(\mu \mathrm{g} / \mathrm{L})]^{(\mathrm{a})}$} \\
\hline & & Range & Average & $\begin{array}{c}\text { Standard } \\
\text { Deviation }^{(\mathrm{c})}\end{array}$ \\
\hline \multicolumn{5}{|c|}{ Ammonia and Anions (contd) } \\
\hline Fluoride & $2 / 2$ & $300-500$ & 400 & - \\
\hline Nitrate & $2 / 2$ & $390-400$ & 400 & - \\
\hline Phosphate & $1 / 2$ & - & 700 & - \\
\hline Sulfate & $2 / 2$ & $14,000-20,000$ & 17,000 & - \\
\hline \multicolumn{5}{|c|}{ Metals } \\
\hline Aluminum & $1 / 2$ & - & 120 & - \\
\hline Barium & $2 / 2$ & $20-27$ & 24 & - \\
\hline Boron & $1 / 2$ & - & 210 & - \\
\hline Cadmium & $1 / 2$ & - & 4.9 & - \\
\hline Calcium & $2 / 2$ & $20,000-21,000$ & 21,000 & - \\
\hline Copper & $2 / 2$ & $32-72$ & 52 & - \\
\hline Iron & $2 / 2$ & $270-290$ & 280 & - \\
\hline Lead & $2 / 2$ & $1.8-2.0$ & 1.9 & - \\
\hline Magnesium & $2 / 2$ & - & 4,500 & - \\
\hline Manganese & $2 / 2$ & $20-29$ & 25 & - \\
\hline Mercury & $2 / 2$ & $0.043-1.3$ & 0.67 & - \\
\hline Nickel & $1 / 2$ & - & 15 & - \\
\hline Potassium & $2 / 2$ & $700-940$ & 820 & - \\
\hline Silicon & $2 / 2$ & $2,200-2,400$ & 2,300 & - \\
\hline Silver & $1 / 2$ & - & 56 & - \\
\hline Sodium & $2 / 2$ & $3,800-11,000$ & 7,400 & - \\
\hline Strontium & $2 / 2$ & $95-97$ & 96 & - \\
\hline Tin & $1 / 2$ & - & 36 & - \\
\hline Zinc & $2 / 2$ & $250-440$ & 350 & - \\
\hline \multicolumn{5}{|c|}{ Volatile Organic Compounds } \\
\hline Acetone & $2 / 2$ & $7.1-9.9$ & 8.5 & - \\
\hline Chloroform & $2 / 2$ & $1.3-2$ & 1.6 & - \\
\hline Ethanol & $1 / 2$ & - & 54 & - \\
\hline Trichloroethene & $2 / 2$ & $0.94-1.3$ & 1.1 & - \\
\hline
\end{tabular}


Table 2.5. (contd)

\begin{tabular}{|c|c|c|c|c|}
\hline \multirow[b]{2}{*}{ Constituent } & \multirow[b]{2}{*}{ Frequency $^{(\mathbf{b})}$} & \multicolumn{3}{|c|}{ Concentration $(\mu \mathrm{g} / \mathrm{L})]^{(\mathbf{a})}$} \\
\hline & & Range & Average & $\begin{array}{c}\text { Standard } \\
\text { Deviation }^{(\mathrm{c})}\end{array}$ \\
\hline \multicolumn{5}{|c|}{ Semivolatile Organic Compounds (Acids/Bases/Neutrals) } \\
\hline $\begin{array}{l}\text { Bis(2-ethylhexyl) } \\
\text { phthalate }\end{array}$ & $2 / 2$ & $1.4-2.0$ & 1.7 & - \\
\hline Diethylphthalate & $1 / 2$ & - & 0.81 & - \\
\hline \multicolumn{5}{|c|}{$\begin{array}{l}\text { (a) Number of samples with detectable concentrations/total number of samples analyzed. } \\
\text { (b) Conductivity units are } \mu \text { mhos } / \mathrm{cm} \text { and radiological parameters are } \mathrm{pCi} / \mathrm{L} \text {. } \\
\text { (c) Two times the standard error of the mean for radiological narameters }\end{array}$} \\
\hline
\end{tabular}

\subsection{Chemical Sciences Laboratory}

Mission and Activities: Work in the 329 Chemical Sciences Laboratory primarily supports Hanford Site environmental restoration and waste management activities. Environmental samples, including soils, vegetation, water, decommissioning materials, and samples of high-level tank waste, are analyzed for all radionuclides and hazardous constituents. Advanced analytical procedures are also developed, tested, and applied.

Staff in the 329 Chemical Sciences Laboratory also conduct R\&D activities in the nuclear sciences, particularly in the areas of radiation instrumentation development and applications, low-level radioactive waste characterization and management, radiological decommissioning, environmental radioactivity measurements, radiochemical separations and measurements, and basic nuclear chemistry and physics.

Physical Description: The 329 Chemical Science Laboratory contains about 40,000 $\mathrm{ft}^{2}$ of floor space on two floors. The building contains general electronics, low-level radiochemistry, and analytical chemistry laboratory space; a neutron multiplier (currently out of service and being dismantled); and associated offices and storage space on the first floor. The second floor is primarily mechanical and electrical rooms.

The 329 Chemical Sciences Laboratory is served by the 300 Area PS, RPS, and SNS. The SNS serves the restrooms and lunchrooms and is also tied into one corridor of the building (C-section) and the main janitor's sink. The RPS serves process areas in the other two corridors (A- and B-sections) that have a greater potential to discharge radioactive materials. Radioactive work in C-Section is primarily with sealed sources. The PS connections serve equipment such as air handling units and drains from an air compressor and vacuum pump. The building is equipped with a liquid effluent sampling system on the RPS that includes capability for continuously monitoring $\mathrm{pH}$, conductivity, and flow, as well as the capability for obtaining flow-composite samples. Because laboratory sinks are not connected to the PS, the risk of inadvertent discharge of inappropriate materials is low and no permanent sampling station has been installed on the PS system. 
Radiological Inventory: A variety of radionuclides may be present in the 329 Chemical Sciences Laboratory. Inventories are generally in small quantities (microcurie to millicurie) and can be in solid, liquid, powder, or sealed source form. In addition, larger quantities (kg or greater) of uranium and thorium may be present as fuel rods, fuel pellets, or powder. Some plutonium may also be present.

Chemical Inventory: A variety of types and forms of chemicals are used in the 329 Chemical Sciences Laboratory, including acids, bases, organics, and inorganics.

Effluent Characterization: The 329 Chemical Sciences Laboratory is equipped with liquid effluent sampling and monitoring ( $\mathrm{pH}$, conductivity, and flow) systems for the RPS, but was not sampled during the sampling campaign conducted by Pacific Northwest's Effluent Management staff in 1994 and 1995 (Thompson et al. 1997). The building was undergoing extensive remodeling during the campaign, and no R\&D work was being conducted in the RPS wings.

Flow rates from the 329 Chemical Sciences Laboratory PS are estimated as approximately $3 \mathrm{gpm}$ and measured flow rates from the RPS are less than $0.1 \mathrm{gpm}$ monthly average. Estimated maximum flow rates are $20 \mathrm{gpm}$ for the PS and $10 \mathrm{gpm}$ for the RPS.

\section{$2.8 \quad 331$ Life Sciences Laboratory I}

Mission and Activities: One of the primary functions of the 331 Life Sciences Laboratory I is to provide research capabilities for studying the health effects of chemicals and radiation and the uptake and transformation effects in soils, plants, animals, microorganisms, and solutions when they are exposed to radiation. Current projects are being conducted to examine these effects in animals and in cells grown in culture. Much of this work focuses on molecular level changes and uses very small amounts of radioactive materials for tracing biological molecules.

Another function of the 331 Life Sciences Laboratory I is to provide aquaculture research capabilities. Aquaculture research conducted in the building provides an integrated approach to characterizing and monitoring aquatic ecosystems by developing and deploying new technologies and methods. Research focuses on the impacts of water-use practices on fisheries and the response of the aquatic ecosystems to engineered structures and to natural and man-induced stresses.

Additionally, research work in the 331 Life Sciences Laboratory I is conducted to promote an understanding of the chemical and biological processes that govern the mobility and degradation of a range of inorganic, organic, and radioactive contaminants in soils, sediments, and groundwater systems. This work may use radioactive materials in more significant quantities.

Finally, research in the 331 Life Sciences Laboratory I is conducted to obtain measurements of exposures to physical and chemical agents. This includes associated research to interpret and validate measurements for providing customers with more accurate and relevant information on worker and public 
exposures and to provide assistance in radioisotope technology to the medical community for diagnosing and treating diseases. For example, a cobalt irradiator is used for a wide variety of exposures from cell cultures to food.

Physical Description: The 331 Life Sciences Laboratory I consists primarily of two laboratory floors with a mechanicalelectrical service floor sandwiched in between. Blending into the building to the west and north is additional single-story laboratory space. From the west end of the building, two wings that were animal kennels extend south. The administrative office area is a three-story building with a twostory addition on the northeast side of the building.

The 331 Life Sciences Laboratory I is served by the 300 Area PS and SNS. The SNS serves the restrooms and lunchrooms, and the PS serves the process areas. In addition, the building has an aquaculture system that serves aquaculture operations and some storm drains. Some of the equipment room and storm water discharges to the aquaculture system were rerouted to the PS in 1998. An animal waste system was also previously used to discharge effluents from animal research areas. This system consisted of a series of connections in the southwest quadrant of the first floor of the facility and a septic tank located northwest of the 331D Biomagnetic Effects Laboratory. In 1998, modifications were made to reroute animal waste lines to the PS after removing restrooms that connected to it in the north wing of building. Samples were taken to confirm the absence of coliform in the effluent stream following the system modifications.

The building is equipped with a liquid effluent sampling system on the PS that includes capability for continuously monitoring $\mathrm{pH}$, conductivity, and flow, as well as the capability for obtaining flowcomposite samples. This system was removed from the original sampling location because of the previously described facility modifications and is in the process of being installed in a new location.

Radiological Inventory: A variety of radionuclides may be present in the 331 Life Sciences Laboratory I. Inventories are generally in small quantities (microcurie to millicurie) and can be in solid, liquid, powder, or sealed source form. In addition, larger quantities (g) of fissionable materials (uranium, neptunium, plutonium) may also be present in gloveboxes.

Chemical Inventory: Chemical storage and usage are dispersed throughout the 331 Life Sciences Laboratory I and consist primarily of small volume chemicals and standards used in conducting laboratory analyses and experiments. Almost all classes of chemicals may be present, including acids, bases, organics, and inorganics.

Effluent Characterization: The 331 Life Sciences Laboratory I is equipped with a liquid effluent sampling system for the PS and was sampled during the sampling campaign conducted by Pacific Northwest's Effluent Management staff in 1994 and 1995 (Thompson et al. 1997). Table 2.6 provides a summary of the results of the sampling campaign. These results show low concentrations (ppb) of pollutants, generally less than the TEDF Waste Acceptance Criteria. PS flow rates are currently estimated at 25 to $30 \mathrm{gpm}$. Maximum flows may be up to $150 \mathrm{gpm}$. 
Table 2.6. Constituents Detected in 331 Life Sciences Laboratory I PS Samples

\begin{tabular}{|c|c|c|c|c|}
\hline \multirow[b]{2}{*}{ Constituent } & \multirow[b]{2}{*}{ Frequency $^{(\mathbf{b})}$} & \multicolumn{3}{|c|}{ Concentration $(\mu \mathrm{g} / \mathrm{L})]^{(\mathrm{a})}$} \\
\hline & & Range & Average & $\begin{array}{c}\text { Standard } \\
\text { Deviation }^{(\mathrm{c})}\end{array}$ \\
\hline \multicolumn{5}{|c|}{ General Chemical Parameters } \\
\hline Alkalinity & $45 / 45$ & $40,000-130,000$ & 68,000 & 20,000 \\
\hline Chemical Oxygen & $32 / 38$ & $6,000-140,000$ & 22,000 & 24,000 \\
\hline Conductivity & $34 / 34$ & $72-920$ & 250 & 150 \\
\hline $\mathrm{pH}$ & $34 / 34$ & $5.1-8.8$ & 7.6 & 0.85 \\
\hline Total Carbon & $38 / 38$ & $14,000-76,000$ & 22,000 & 10,000 \\
\hline Total Dissolved Solids & $43 / 43$ & $90,000-480,000$ & 140,000 & 62,000 \\
\hline Total Organic Carbon & $44 / 44$ & $2,000-61,000$ & 6,500 & 9,000 \\
\hline \multicolumn{5}{|c|}{ Ammonia and Anions } \\
\hline Ammonia & $34 / 45$ & $30-1,000$ & 140 & 230 \\
\hline Bromide & $2 / 42$ & $140-200$ & 170 & - \\
\hline Chloride & $43 / 43$ & $3,600-170,000$ & 11,000 & 24,000 \\
\hline Cyanide & $33 / 43$ & $1-70$ & 17 & 20 \\
\hline Fluoride & $43 / 43$ & $300-1,100$ & 640 & 150 \\
\hline Nitrate & $43 / 43$ & $300-33,000$ & 6,100 & 7,900 \\
\hline Nitrite & $2 / 35$ & $110-130$ & 120 & - \\
\hline Phosphate & $31 / 43$ & $210-82,000$ & 7,100 & 15,000 \\
\hline Sulfate & $43 / 43$ & $10,000-48,000$ & 19,000 & 5,800 \\
\hline Sulfides & $12 / 38$ & $200-400$ & 240 & 64 \\
\hline \multicolumn{5}{|c|}{ Metals } \\
\hline Aluminum & $43 / 44$ & $22-630$ & 150 & 160 \\
\hline Arsenic & $5 / 44$ & $2-3$ & 2.4 & 0.5 \\
\hline Barium & $44 / 44$ & $17-48$ & 29 & 6 \\
\hline Beryllium & $1 / 44$ & - & 0.19 & - \\
\hline Cadmium & $2 / 44$ & - & 3.4 & - \\
\hline Calcium & $44 / 44$ & $16,000-43,000$ & 24,000 & 6,300 \\
\hline Chromium & $6 / 44$ & $4.3-22$ & 13 & 8 \\
\hline Copper & $44 / 44$ & $9.5-930$ & 51 & 140 \\
\hline Iron & $42 / 44$ & $18-460$ & 85 & 78 \\
\hline Lead & $36 / 44$ & $0.6-17$ & 2.5 & 2.8 \\
\hline Magnesium & $44 / 44$ & $3,900-18,000$ & 5,500 & 2,200 \\
\hline Manganese & $35 / 44$ & $1-16$ & 3.4 & 3.3 \\
\hline Mercury & $11 / 44$ & $0.055-0.17$ & 0.096 & 0.036 \\
\hline Nickel & $2 / 44$ & $16-17$ & 17 & - \\
\hline Potassium & $43 / 44$ & $940-12,000$ & 3,400 & 2,500 \\
\hline
\end{tabular}


Table 2.6. (contd)

\begin{tabular}{|c|c|c|c|c|}
\hline \multirow[b]{2}{*}{ Constituent } & \multirow[b]{2}{*}{ Frequency $^{(\mathbf{b})}$} & \multicolumn{3}{|c|}{ Concentration $(\mu \mathrm{g} / \mathrm{L})]^{(\mathrm{a})}$} \\
\hline & & Range & Average & $\begin{array}{c}\text { Standard } \\
\text { Deviation }^{(\mathrm{c})}\end{array}$ \\
\hline \multicolumn{5}{|c|}{ Metals (contd) } \\
\hline Selenium & $5 / 44$ & $0.95-2$ & 1.5 & 0.51 \\
\hline Silicon & $2 / 2$ & $3,000-3,200$ & 3,100 & - \\
\hline Silver & $2 / 44$ & $3.6-7.1$ & 5.4 & - \\
\hline Sodium & $44 / 44$ & $3,300-110,000$ & 13,000 & 17,000 \\
\hline Strontium & $3 / 3$ & $93-110$ & 100 & 9 \\
\hline Thallium & $4 / 44$ & $0.58-1.1$ & 0.83 & 0.21 \\
\hline Tin & $5 / 44$ & $24-110$ & 71 & 31 \\
\hline Vanadium & $6 / 44$ & $2-7.8$ & 4.3 & 2.6 \\
\hline Zinc & $44 / 44$ & $22-230$ & 67 & 39 \\
\hline \multicolumn{5}{|c|}{ Volatile Organic Compounds } \\
\hline 1,1,1-Trichloroethane & $1 / 66$ & - & 2.1 & - \\
\hline 2-Butanone & $3 / 66$ & $51-170$ & 100 & 61 \\
\hline Acetone & $15 / 66$ & $5.6-1,800$ & 140 & 460 \\
\hline Acetonitrile & $1 / 26$ & - & 430 & - \\
\hline Bromodichloromethane & $16 / 34$ & $0.5-9.8$ & 2.3 & 2.3 \\
\hline Bromoform & $1 / 34$ & - & 26 & - \\
\hline Chlorobenzene & $1 / 26$ & - & 0.39 & - \\
\hline Chloroform & $66 / 66$ & $3.1-33$ & 11 & 6.5 \\
\hline Dibromochloromethane & $6 / 34$ & $0.7-11$ & 2.7 & 4.1 \\
\hline Ethanol & $5 / 66$ & $8.3-47$ & 21 & 15 \\
\hline Hexone & $4 / 66$ & $1.9-19$ & 11 & 9.2 \\
\hline Isopropyl alcohol & $1 / 66$ & - & 19 & - \\
\hline Methylene chloride & $43 / 66$ & $0.4-4.8$ & 1.2 & 0.9 \\
\hline Tetrahydrofuran & $2 / 66$ & $0.52-3$ & 1.8 & - \\
\hline Toluene & $4 / 66$ & $0.22-0.86$ & 0.53 & 0.26 \\
\hline Trichloroethene & $3 / 66$ & $0.51-0.91$ & 0.77 & 0.23 \\
\hline Xylenes (total) & $3 / 66$ & $1.4-2.4$ & 1.8 & 0.5 \\
\hline \multicolumn{5}{|c|}{ Semivolatile Organic Compounds (Acids/Bases/Neutrals) } \\
\hline Benzyl alcohol & $3 / 15$ & $4.1-34$ & 22 & 16 \\
\hline Bis(2-ethylhexyl) & $8 / 46$ & $1-6.4$ & 3.7 & 2.3 \\
\hline Decane & $1 / 32$ & - & 37 & - \\
\hline Di-n-butylphthalate & $4 / 14$ & $2-3.6$ & 2.5 & 0.8 \\
\hline Kerosene & $1 / 14$ & - & 9.5 & - \\
\hline Phenol & $4 / 46$ & $1-4.9$ & 2.5 & 1.8 \\
\hline
\end{tabular}


Table 2.6. (contd)

\begin{tabular}{|c|c|c|c|c|}
\hline \multirow[b]{2}{*}{ Constituent } & \multirow[b]{2}{*}{ Frequency $^{(b)}$} & \multicolumn{3}{|c|}{ Concentration $(\boldsymbol{\mu g} / \mathrm{L})]^{(\mathbf{a})}$} \\
\hline & & Range & Average & $\begin{array}{c}\text { Standard } \\
\text { Deviation }^{(\mathrm{c})}\end{array}$ \\
\hline \multicolumn{5}{|c|}{ Semivolatile Organic Compounds (Pesticides) } \\
\hline 4,4'-DDE & $3 / 40$ & $0.0017-0.72$ & 0.24 & 0.41 \\
\hline Aldrin & $1 / 40$ & - & 0.011 & - \\
\hline Alpha - BHC & $3 / 40$ & $0.0036-0.0073$ & 0.0057 & 0.0019 \\
\hline Beta - BHC & $4 / 40$ & $0.0099-0.026$ & 0.017 & 0.0083 \\
\hline Delta - BHC & $10 / 40$ & $0.0017-0.033$ & 0.011 & 0.0088 \\
\hline Dieldrin & $1 / 40$ & - & 0.0032 & - \\
\hline Endosulfan I & $6 / 40$ & $0.0018-0.005$ & 0.0032 & 0.001 \\
\hline Endrin & $2 / 40$ & $0.0025-0.0066$ & 0.0046 & - \\
\hline Endrin aldehyde & $1 / 40$ & - & 0.012 & - \\
\hline Gamma-BHC & $5 / 40$ & $0.0023-0.0038$ & 0.0029 & 0.0007 \\
\hline Methoxychlor & $1 / 40$ & - & 0.019 & - \\
\hline \multicolumn{5}{|c|}{ Radiological Parameters } \\
\hline Gross Alpha & $19 / 47$ & $0.91-8.3$ & 3.0 & 0.47 \\
\hline Gross beta & $27 / 47$ & $2.1-15$ & 5.2 & 0.58 \\
\hline Tritium & $1 / 2$ & - & 330 & - \\
\hline
\end{tabular}

\subsection{D Biomagnetic Effects Laboratory}

Mission and Activities: The 331D Building, which was used in the past as a biomagnetic effects laboratory, is currently used to store equipment and supplies, including portable samplers, $\mathrm{pH}$ meters, bottles, buffer solutions, and concentrated dyes in support of Pacific Northwest- and Battelle-compliance monitoring activities. Nonradioactive wastewater samples are temporarily stored at this facility before shipment to various analytical laboratories. Additionally, chemicals used in facility and 300 Area mechanical systems are stored in a back room for Pacific Northwest's Maintenance Services Organization.

Physical Description: The 331D Biomagnetic Effects Laboratory is a semi-high-bay, prefabricated, metal Butler building erected on a concrete slab and is located to the southeast of the 331 Life Sciences Laboratory I. The structure is approximately $42 \mathrm{ft}$ by $32 \mathrm{ft}$ (1344 ft of floor space) and was originally built as an animal waste treatment facility. It has three large rooms; one is equipped with a sink, cabinets, and a counter top. This room, with about one-third of the floor space, is considered to be a wet and dry lab, and has one drain to the PS. The other two rooms, which constitute the remaining two-thirds of the floor space, are used for storage. 
Radiological Inventory: No radiological materials are permitted within the 331D Biomagnetic Effects Laboratory.

Chemical Inventory: Small quantities of chemicals may be present in the 331D Biomagnetic Effects Laboratory to support effluent sampling and monitoring operations (e.g., pH buffers, standards, preservatives in sampling bottles). Bulk chemicals that are used for facility operations are also stored in the building.

Effluent Characterization: The 331D Biomagnetic Effects Laboratory is primarily used for storage with very minor and periodic discharges from the use of one lab sink. Discharge flow rates are estimated at less than $1 \mathrm{gpm}$, and no effluent sampling or monitoring has been performed.

\subsection{G Interim Tissue Repository}

Mission and Activities: The 331G Interim Tissue Repository provides research capabilities for conducting radioactive tracer studies using animals, biota, vegetation, and soils. In the main 331 Life Sciences Laboratory I, small quantities of tracer radionuclides are deposited in soil, taken up by vegetation, and fed to small animals. In the $331 \mathrm{G}$ Interim Tissue Repository, some of these animals may be temporarily housed and their excrements stored in closed containers.

Physical Description: The $331 \mathrm{G}$ Interim Tissue Repository is a $60-\mathrm{ft}$ by 20 - $\mathrm{ft}\left(1200 \mathrm{ft}^{2}\right)$ concrete block structure on a concrete slab and is located to the extreme southeast of the 331 Life Sciences Laboratory I. The building was originally built to house laboratory animals (primarily swine) while they were giving birth, but is now used in support of animal research. Almost all of the floor space is considered dry laboratory. A sink and two floor trenches from this facility are routed to the PS.

Radiological Inventory: Small (millicurie) quantities of ${ }^{14} \mathrm{C},{ }^{3} \mathrm{H},{ }^{32} \mathrm{P}$, or ${ }^{35} \mathrm{~S}$ may be present in the animals or excrement samples.

Chemical Inventory: No chemicals are stored in the 331G Interim Tissue Repository other than those present in the animals or excrement samples.

Effluent Characterization: No effluents are discharged to the floor drains from the $331 \mathrm{G}$ Interim Tissue Repository, and no effluent sampling or monitoring has been performed.

\subsection{H Aerosol Wind Tunnel Research Facility}

Mission and Activities: In the 331H Aerosol Wind Tunnel Research Facility, research is conducted to evaluate the effects and changes in plants, animals, and the surface geologic materials occurring as a result of airborne deposition of windblown materials, chemical constituents, or wind erosion. The facility houses a wind tunnel, associated measurement equipment, and a lab area to perform these studies. 
Physical Description: The 331H Aerosol Wind Tunnel Research Facility is a one-story, concrete block structure on concrete foundations and a concrete slab. It is located southeast of the 331 Life Sciences Laboratory I. The building has a flat, built-up roof covered with gravel. A metal lean-to is attached to the northwest corner of the building to provide additional research space. A little over half of the $3600-\mathrm{ft}^{2}$ floor space is considered dry or wet laboratory; the remainder is considered common space. A humidifier and condensate drains are routed to the PS from this facility.

Radiological Inventory: Sealed sources for measurement equipment are the only radiological materials in the $331 \mathrm{H}$ Aerosol Wind Tunnel Research Facility.

Chemical Inventory: A wide variety of chemicals may be present in the $331 \mathrm{H}$ Aerosol Wind Tunnel Research Facility in support of or as part of the wind tunnel experiments.

Effluent Characterization: Very minor quantities of effluent are generated in the $331 \mathrm{H}$ Aerosol Wind Tunnel Research Facility, and no effluent sampling or monitoring has been performed.

\subsection{High-Bay Testing Facility}

Mission and Activities: The primary mission of the 336 High-Bay Testing Facility is the engineering and analysis of multiphase flow experiments. Near-term objectives support model development and code assessment activities to continue involvement in basic research related to multiphase flow phenomena, and to experimentally address issues related to Hanford waste retrieval, transport, and disposal. Activities within this building's Fluid Dynamics Laboratory include bubble dynamics experiments, slurry transport/resuspension studies, and waste tank mixing/mitigation/retrieval experiments using a variety of nonradioactive physical simulants. Major building equipment/systems include the 1/4- and 1/12-scale waste tank models, a scaled waste retrieval/pneumatic conveyance test facility, and numerous other semipermanent to temporary test articles and facilities.

Work activities conducted by research staff include the development and assessment of waste retrieval and transport technologies. A multiscale tanks system (1/4, 1/12, and 1/25 scale of double-shell tanks) and ancillary equipment are used to accommodate the full-technology development cycle for retrieval technologies such as pulsed-air, pneumatic conveyance, and extendable nozzle. Additional studies are performed to enhance or better understand existing technologies such as aerosol generation during sluicing and performance correlations for mixer pumps. A 3-in. slurry test loop is used to test the performance of candidate instruments for monitoring slurry transport through pipes. An adjacent simulant development and measurements laboratory supports the high-bay testing and houses state-of-theart instruments that provide a wide range of physical properties important to waste retrieval and transport.

Physical Description: The 336 High-Bay Testing Facility provides staff with a three-story high-bay and a 20-ft-diameter circular pit, approximately 50-ft deep. The approximately 4,000- $\mathrm{ft}^{2}$ building houses a series of tanks up to about a 25,000-gal capacity. The southwest corner of the building provides two supporting laboratories. 
The 336 High-Bay Testing Facility is served by the 300 Area PS and SNS; the SNS serves the restrooms, and the PS serves process areas. The building does not have a liquid effluent sampling system.

Radiological Inventory: Radiological materials are not permitted within the 336 High-Bay Testing Facility.

Chemical Inventory: Bulk chemicals are used in the slurry studies and smaller quantities also are used to support research activities. A variety of types and forms of chemicals are used in the 336 High-Bay Testing Facility.

Effluent Characterization: Discharges from the 336 High-Bay Testing Facility are very low ( $<1 \mathrm{gpm})$, and no effluent sampling monitoring has been performed.

\subsection{Technical Management Center}

Mission and Activities: The 337 Technical Management Center is primarily an office complex that houses Pacific Northwest support groups (e.g., Environment, Safety and Health; Facilities and Operations). The only sources of effluents are steam condensate and cooling water from two equipment rooms.

Physical Description: The 337 Technical Management Center is a large, three-story structure that provides staff with office space, conference rooms, and a cafeteria. A large mechanical equipment room serves the main building, and a smaller mechanical equipment room serves the cafeteria. Although most wastewater from the building is discharged to the SNS, the two equipment rooms have discharges to the PS.

Radiological Inventory: No radiological material is permitted in the 337 Technical Management Center.

Chemical Inventory: The only chemicals used in the 337 Technical Management Center are those needed for cleaning or in support of facility equipment.

Effluent Characterization: Estimated flow rates from the 337 Technical Management Center are about $5 \mathrm{gpm}$ from one equipment room and about $3 \mathrm{gpm}$ from the other. Both equipment rooms have sumps that periodically pump to the PS. Therefore, maximum flow rates may be 30 to $50 \mathrm{gpm}$. No effluent sampling or monitoring has been performed.

\subsection{Prototype Engineering Laboratory}

Mission and Activities: The principal effort in the 338 Prototype Engineering Laboratory is focused on assembling and testing equipment to be used by the DOE client. The work uses nonradioactive materials. A portable x-ray machine may be used. A second project is being conducted in the high-bay portion of the building using the Variable Geometry truss robot. 
The 338 Prototype Engineering Laboratory houses materials processing laboratories that consist of several metals processing capabilities centered around aluminum and light metal development and casting of lightweight materials and advanced metal composites. The Thermo-Mechanical Processing Laboratory within this building consists of a rolling mill, heat-treating furnaces, and brake shear. A second major processing laboratory is the MetalCasting Laboratory. The laboratory consists of two induction power units, a centrifugal casting unit, meltspin caster, a die casting coatings evaluation unit, and associated equipment for sectioning, mixing, and heat treating cast materials. The drop tower will be used for coining of cast gears and is an element of the casting and processing laboratory.

Physical Description: The 338 Prototype Engineering Laboratory is a one-story building containing about $18,000 \mathrm{ft}^{2}$ of floor space. The building consists of office, high-bay, and support space. The building also has a large basement area.

The 338 Prototype Engineering Laboratory is served by the 300 Area PS and SNS; the SNS serves the restrooms, and the PS serves process areas. The building does not have a liquid effluent sampling system.

Radiological Inventory: Radiological materials are not permitted within the 338 Prototype Engineering Laboratory.

Chemical Inventory: Very few chemicals are used in the 338 Prototype Engineering Laboratory other than a few organics and bottled gases.

Effluent Characterization: Average flow rates from the 338 Prototype Engineering Laboratory are very low (estimated at $<1 \mathrm{gpm}$ ) and are primarily from lunchroom sinks and air conditioner condensate. The estimated maximum flow rate is 20 gpm. No effluent sampling or monitoring has been performed.

\subsection{Environmental Sciences Laboratory}

Mission and Activities: The 3720 Environmental Sciences Laboratory provides office and laboratory space for Pacific Northwest scientific and engineering staff conducting multidisciplinary research in the areas of materials characterization and testing and waste management. The building is designed to accommodate the use of radioactive and hazardous materials to conduct these activities. The building is currently in the process of being vacated. However, there is no current schedule on removal of several activities within the building, and these activities include those that generate liquid effluents. Therefore, the building is still considered a potentially significant contributor to the PS effluent stream.

Physical Description: The 3720 Environmental Sciences Laboratory contains over $29,000 \mathrm{ft}^{2}$ of floor space and is an all-metal frame construction erected on concrete foundations, footings, and floor slab. The building includes 34 offices $\left(4,300 \mathrm{ft}^{2}\right)$, 30 laboratories $\left(13,000 \mathrm{ft}^{2}\right)$, storage space $\left(1,000 \mathrm{ft}^{2}\right)$, and common space $\left(11,000 \mathrm{ft}^{2}\right)$. The facility also contains a $24-\mathrm{ft} \times 109-\mathrm{ft}$ basement area at the southwest corner. An annex that contains laboratories has been added to the north end of the building. Currently, only a small portion of the building is being used. 
The 3720 Environmental Sciences Laboratory is served by the 300 Area PS and SNS; the SNS serves the restrooms, lunchrooms, and one laboratory, and the PS serves all other process areas. PS effluents are discharged to a sump that is emptied using an eductor. The building is equipped with a liquid effluent sampling system on the PS that includes capability for continuously monitoring $\mathrm{pH}$, conductivity, and flow, as well as the capability for obtaining flow-composite samples.

Radiological Inventory: A wide variety of radionuclides and forms may be present in the 3720 Environmental Sciences Laboratory. The counting laboratory has smaller (microcurie to millicurie) quantities of radionuclides, and research activities may involve several grams. Materials may be present as powders/soils, liquids, in a glass matrix, or as sealed sources.

Chemical Inventory: Chemical storage and usage were dispersed throughout the 3720 Environmental Sciences Laboratory when the building was fully staffed. Now chemicals are located primarily in the remaining occupied areas. These chemicals may include bulk materials (solvents, acids, bases), specimen materials used in materials characterization, substrate materials used to perform laboratory experiments (e.g., chelating agents, salts, inorganics) and standards used for instrument calibration.

Effluent Characterization: The 3720 Environmental Sciences Laboratory is equipped with a liquid effluent sampling system for the PS and was sampled during the sampling campaign conducted by Pacific Northwest's Effluent Management staff in 1994 and 1995 (Thompson et al. 1997). Table 2.7 provides a summary of the results of the sampling campaign and lists the average concentrations from samples taken from normal work days. These results show low concentrations ( $\mathrm{ppb}$ ) of pollutants, generally less than the TEDF Waste Acceptance Criteria. PS flow rates have been measured and the monthly averages range from $<1$ to $6 \mathrm{gpm}$. With the current limited activities in the building, flows have been $<1 \mathrm{gpm}$ for the past year. Maximum flows may be up to 70 gpm.

Table 2.7. Constituents Detected in the 3720 Environmental Sciences Laboratory PS Samples

\begin{tabular}{||l|c|l|l|c||}
\hline \multicolumn{5}{|c||}{ General Chemical Parameter $(\boldsymbol{\mu g} / \mathbf{L})$} \\
\hline Alkalinity & 55,744 & & Total Carbon & 17,800 \\
\hline $\begin{array}{l}\text { Chemical Oxygen } \\
\text { Demand }\end{array}$ & 11,552 & & Total Dissolved Solids & 106,341 \\
\hline Conductivity & $197(\mu \mathrm{mhos} / \mathrm{cm})$ & & Total Organic Carbon & 2,876 \\
\hline $\mathrm{pH}$ & $7.75($ unitless $)$ & & \\
\hline \multicolumn{5}{|c|}{ Ammonia and Anions $(\boldsymbol{\mu g} / \mathbf{L})$} \\
\hline Ammonia & 63 & & Nitrate & 3,513 \\
\hline Chloride & 5,911 & & Phosphate & 699 \\
\hline Cyanide & 4.4 & & Sulfate & 15,733 \\
\hline Fluoride & 506 & & Sulfides & 231 \\
\hline
\end{tabular}


Table 2.7. (contd)

\begin{tabular}{|c|c|c|c|}
\hline \multicolumn{4}{|c|}{ Metals ( $\mu \mathrm{g} / \mathrm{L})$} \\
\hline Aluminum & 70 & Manganese & 3.90 \\
\hline Antimony & 33 & Mercury & 0.19 \\
\hline Arsenic & 2.0 & Nickel & 17 \\
\hline Barium & 29 & Potassium & 1,325 \\
\hline Beryllium & 0.18 & Selenium & 1.18 \\
\hline Cadmium & 4.0 & Silicon & 2,650 \\
\hline Calcium & 21,674 & Sodium & 5,216 \\
\hline Chromium & 11.4 & Strontium & 96 \\
\hline Cobalt & 6.9 & Thallium & 1.03 \\
\hline Copper & 19.7 & Tin & 47 \\
\hline Iron & 96 & Vanadium & 3.1 \\
\hline Lead & 3.4 & Zinc & 65 \\
\hline Magnesium & 4,728 & & \\
\hline \multicolumn{4}{|c|}{ Volatile Organic Compounds $(\mu \mathrm{g} / \mathrm{L})$} \\
\hline 1,1,2-Trichloroethane & 0.75 & Ethanol & 14.1 \\
\hline 1,2-Dichloroethylene & 0.68 & Ethylbenzene & 0.63 \\
\hline Acetone & 72.9 & Hexone & 13.3 \\
\hline Acetonitrile & 1,075 & Isopropyl Alcohol & 15.8 \\
\hline Benzene & 0.51 & Methylene Chloride & 1.36 \\
\hline Bromodichloromethane & 1.2 & Tetrahydrofuran & 53.4 \\
\hline Carbon Disulfide & 2.5 & Toluene & 69.39 \\
\hline Chloroform & 12.9 & Trichloroethene & 1.28 \\
\hline Dibromochloromethane & 1.7 & Xylenes (total) & 2.3 \\
\hline \multicolumn{4}{|c|}{ Semi-volatile Organic Compounds $(\mu \mathrm{g} / \mathrm{L})$} \\
\hline Bis(2-ethylhexyl)phthalate & 3.18 & Phenol & 3.8 \\
\hline Di-n-butylphthalate & 2.5 & Tributyl Phosphate & 4.66 \\
\hline Diethylphthalate & 81 & & \\
\hline \multicolumn{4}{|c|}{ Radiological Parameters (pCi/L) } \\
\hline Gross Alpha & 12.07 & Uranium-235 & 0.346 \\
\hline Gross Beta & 5.31 & Uranium-238 & 6.5 \\
\hline Uranium-234 & 7.96 & & \\
\hline
\end{tabular}

\subsection{Gamma Irradiation Facility}

Mission and Activities: The 3730 Gamma Irradiation Facility plays an important role in a wide range of programs (e.g., analysis of Hanford waste tank solutions, corrosion and stress-corrosion cracking studies, and the evaluation of various types of probes under irradiated conditions). The effect of gamma radiation 
on different materials is evaluated in this building. Activities also include measuring the density of materials and the receiving, sorting, and shipping of radioactive materials.

Physical Description: The 3730 Gamma Irradiation Facility is a one-story, concrete block structure with approximately 4,000 $\mathrm{ft}^{2}$ of floor space and is equipped with a hot cell. The building is served by the 300 Area PS and SNS; the SNS serves the restrooms and lunchrooms, and the PS serves process areas. No liquid effluent sampling system exists for the building.

Radiological Inventory: Curie quantities of radioactive materials in solid form are stored and tested in the 3730 Gamma Irradiation Facility.

Chemical Inventory: A variety of types and forms of chemicals are used in the 3730 Gamma Irradiation Facility.

Effluent Characterization: The estimated average daily flow rate is very low ( $<1 \mathrm{gpm})$ with an estimated maximum of $10 \mathrm{gpm}$. No effluent sampling or monitoring has been performed. 
This page intentionally left blank.

Issued: June 2000

PNNL-13276, Rev. 2

Supersedes: Rev. 1

Page 36 


\subsection{References}

Fluor Hanford Company. 2000. 300 LEF Project Administration Procedures, RCP-310, Fluor Hanford Company, Richland, Washington.

Pacific Northwest National Laboratory. 1998. Managing Liquid Effluents.

(http://sbms.pnl.gov/standard/0q/0q00t010.htm), Standards-Based Management System subject area, Pacific Northwest National Laboratory, Richland, Washington.

Pacific Northwest National Laboratory. 1998. Managing Nonradioactive Chemical Waste. (http://sbms.pnl.gov/standard/0f/0f00t010.htm), Standards-Based Management System subject area, Pacific Northwest National Laboratory, Richland, Washington.

Pacific Northwest National Laboratory. 1999. Spill Response.

(http://sbms.pnl.gov/standard/0e/0e00t010.htm), Standards-Based Management System subject area, Pacific Northwest National Laboratory, Ric hland, Washington.

Pacific Northwest National Laboratory. 1999. Training and Qualification for Staff. (http://sbms.pnl.gov/standard/1e/1e00t010.htm), Standards-Based Management System subject area, Pacific Northwest National Laboratory, Richland, Washington.

Pacific Northwest National Laboratory. 1997. Waste Minimization and Pollution Prevention. (http://sbms.pnl.gov/standard/0z/0z00t010.htm), Standards-Based Management System subject area, Pacific Northwest National Laboratory, Richland, Washington.

Pacific Northwest National Laboratory. 1998. Working With Chemicals.

(http://sbms.pnl.gov/standard/03/0300t010.htm ), Standards-Based Management System subject area, Pacific Northwest National Laboratory, Richland, Washington.

Thompson, CJ, MY Ballinger, EG Damberg, and RG Riley. 1997. Characterization and Monitoring of 300 Area Facility Liquid Waste Streams During 1994 and 1995. PNNL-11552, Pacific Northwest National Laboratory, Richland, Washington.

U.S. Department of Energy. 1990. "Radiation Protection of the Public and the Environment." DOE 5400.5, U.S. Department of Energy, Washington, D.C. 
This page intentionally left blank.

Issued: June 2000

PNNL-13276, Rev. 2

Supersedes: Rev. 1

Page 38 


\section{Appendix A}

\section{Sampling Event}


This page intentionally left blank.

Issued: June 2000

PNNL-13276, Rev. 2

Supersedes: Rev. 1

Page 40 


\section{Appendix A}

\section{Sampling Event}

In May 1998, a single sampling event was conducted at each of the Pacific Northwest National Laboratory (Pacific Northwest) dedicated sampling stations to affirm that liquid effluents were not significantly different from previous characterization efforts. In this effort, a series of grab samples were taken at selected times over a 2-week period and then composited and analyzed. Samples were taken from sampling stations at the 320, 325, 326 Process Sewer (PS), 326 Retention Process Sewer (RPS), 329 RPS, 331, and 3720 sampling stations at 11:00 a.m. and at 3:00 p.m. from May 11 to May 15 and from May 18 to May 22. The times were selected to maximize potential laboratory discharges over the 2 -week period. Samples were composited and analyzed for total organic carbon, ammonia, cyanide, and metals. Screening for radiological constituents (gross alpha and gross beta) were performed for effluent samples from the Retention Process Sewer and from the 3720 Environmental Sciences Laboratory.

Table A.1 shows the results that confirm previous sampling performed in 1994 and 1995 from the Pacific Northwest 300 Area facilities. Concentrations for metals are low, in the micrograms per liter $(\mu \mathrm{g} / \mathrm{L})$ range. Some metals such as copper and zinc may be above the Treated Effluent Disposal Facility Waste Acceptance Criteria in facility discharges, but are not expected to be above the Waste Acceptance Criteria when flows from all Pacific Northwest facilities are combined. These metals are believed to be from facility piping. 
Table A.1. Analytical Results for 1998 Single Event Sampling

\begin{tabular}{|c|c|c|c|c|c|c|c|}
\hline \multirow[b]{2}{*}{ Constituent } & \multicolumn{7}{|c|}{$\begin{array}{c}\text { Concentration in Facility Effluent } \\
\text { [Units are milligrams per liter }(\mathrm{mg} / \mathrm{L}) \text { unless otherwise provided] }\end{array}$} \\
\hline & 320 & 325 & $326 \mathrm{PS}$ & 326 RPS & 329 & 331 & 3720 \\
\hline $\begin{array}{l}\text { Total Organic } \\
\text { Carbon }\end{array}$ & 2.2 & 5.5 & 4.4 & 130 & 7.8 & 7.1 & 2.6 \\
\hline $\begin{array}{l}\text { N-Ammonia, } \\
\mathrm{mg}-\mathrm{N} / \mathrm{L}\end{array}$ & 0.015 & 0.070 & 0.040 & 0.057 & 0.3 & 0.018 & 0.011 \\
\hline $\begin{array}{l}\text { Total } \\
\text { Cyanide }\end{array}$ & $<0.004 \mathrm{U}$ & $<0.004 \mathrm{U}$ & $<0.004 \mathrm{U}$ & $<0.004 \mathrm{U}$ & $<0.004 \mathrm{U}$ & $<0.004 \mathrm{U}$ & $<0.004 \mathrm{U}$ \\
\hline Aluminum & 0.03 & 0.04 & 0.20 & 0.10 & 0.14 & 0.14 & 0.04 \\
\hline Antimony & $<0.001 \mathrm{U}$ & $<0.001 \mathrm{U}$ & $<0.001 \mathrm{U}$ & $<0.001 \mathrm{U}$ & $<0.001 \mathrm{U}$ & $<0.001 \mathrm{U}$ & $<0.001 \mathrm{U}$ \\
\hline Arsenic & $<0.001 \mathrm{U}$ & $<0.001 \mathrm{U}$ & $<0.001 \mathrm{U}$ & $<0.001 \mathrm{U}$ & $<0.001 \mathrm{U}$ & $<0.001 \mathrm{U}$ & $<0.001 \mathrm{U}$ \\
\hline Beryllium & $<0.001 \mathrm{U}$ & $<0.001 \mathrm{U}$ & $<0.001 \mathrm{U}$ & $<0.001 \mathrm{U}$ & $<0.001 \mathrm{U}$ & $<0.001 \mathrm{U}$ & $<0.001 \mathrm{U}$ \\
\hline Cadmium & $<0.0002 \mathrm{U}$ & $<0.0002 \mathrm{U}$ & 0.006 & 0.0047 & 0.0013 & 0.0003 & $<0.0002 \mathrm{U}$ \\
\hline Chromium & $<0.005 \mathrm{U}$ & $<0.005 \mathrm{U}$ & 0.006 & $<0.005 \mathrm{U}$ & $<0.005 \mathrm{U}$ & $<0.005 \mathrm{U}$ & $<0.005 \mathrm{U}$ \\
\hline Copper & 0.01 & 0.027 & 0.248 & 0.437 & 0.482 & 0.021 & 0.011 \\
\hline Iron & 0.07 & 0.31 & 1.40 & 0.77 & 0.11 & 0.03 & 0.08 \\
\hline Lead & $<0.001 \mathrm{U}$ & 0.002 & 0.005 & 0.030 & 0.03 & 0.002 & $<0.001 \mathrm{U}$ \\
\hline Manganese & 0.002 & 0.014 & 0.021 & 0.039 & 0.004 & 0.002 & 0.005 \\
\hline Mercury & $<0.0001 \mathrm{U}$ & 0.0010 & $<0.0001 \mathrm{U}$ & 0.0022 & 0.0004 & $<0.0001 \mathrm{U}$ & $<0.0001 \mathrm{U}$ \\
\hline Nickel & $<0.01 \mathrm{U}$ & $<0.01 \mathrm{U}$ & $<0.01 \mathrm{U}$ & 0.01 & 0.02 & $<0.01 \mathrm{U}$ & $<0.01 \mathrm{U}$ \\
\hline Selenium & $<0.001 \mathrm{U}$ & $<0.001 \mathrm{U}$ & $<0.001 \mathrm{U}$ & $<0.001 \mathrm{U}$ & $<0.001 \mathrm{U}$ & $<0.001 \mathrm{U}$ & $<0.001 \mathrm{U}$ \\
\hline Silver & $<0.0002 \mathrm{U}$ & 0.0004 & 0.070 & 0.0037 & 0.0022 & $<0.0002 \mathrm{U}$ & 0.0006 \\
\hline Thallium & $<0.001 \mathrm{U}$ & $<0.001 \mathrm{U}$ & $<0.001 \mathrm{U}$ & $<0.001 \mathrm{U}$ & $<0.001 \mathrm{U}$ & $<0.001 \mathrm{U}$ & $<0.001 \mathrm{U}$ \\
\hline Zinc & 0.078 & 0.171 & 0.338 & 2.35 & 0.067 & 0.064 & 0.044 \\
\hline $\begin{array}{l}\text { Gross Alpha, } \\
\text { picocuries per } \\
\text { milliliter } \\
(\mathrm{pCi} / \mathrm{mL})\end{array}$ & & $<2 \mathrm{E}-3$ & & $<2 \mathrm{E}-3$ & $<2 \mathrm{E}-3$ & & $<2 \mathrm{E}-3$ \\
\hline $\begin{array}{l}\text { Gross Beta, } \\
\mathrm{pCi} / \mathrm{mL}\end{array}$ & & $4.63 \mathrm{E}-3$ & & $<3 \mathrm{E}-3$ & $8.30 \mathrm{E}-3$ & & $1.46 \mathrm{E}-2$ \\
\hline
\end{tabular}




\section{Appendix B}

\section{Sampling Event}


This page intentionally left blank.

Issued: June 2000

PNNL-13276, Rev. 2

Supersedes: Rev. 1

Page 44 


\section{Appendix B}

\section{Sampling Event}

In February 2000, a single sampling event was conducted at each of the Pacific Northwest National Laboratory (Pacific Northwest) dedicated sampling stations in response to an occurrence declared by the Treated Effluent Disposal Facility (TEDF) for elevated alpha levels in the Process Sewer (PS). Sampling took place on February 8 and 9, and samples were analyzed at the 325 Building analytical laboratory for gross alpha, gross beta, and tritium. The location, type of sample, and results are shown in Table B.1.

With the exception of 3720 , all gross alpha analyses indicate no contamination or levels below the TEDF baseline for gross alpha in the PS ( 3 pCi/L). Similarly, all gross beta analyses except 3720 indicate no contamination or levels far below the TEDF Waste Acceptance Criteria for gross beta levels in the PS $(15 \mathrm{pCi} / \mathrm{L})$. Although levels found in the manhole used to collect the 3720 sample are significantly higher than at other sample locations, they are not high enough to have caused the elevated alpha contamination levels seen at the TEDF. Additional sampling performed at the TEDF indicate that sediments in the 300 Area PS system were the most likely the source of the contamination. 
Table B.1. Analytical Results for 2000 Sampling Event

\begin{tabular}{|c|c|c|c|c|c|c|}
\hline Building & System & Location & Sample Type & $\begin{array}{l}\text { Tritium }^{(\mathbf{a})} \\
\text { [picocuries } \\
\text { per liter } \\
(\mathrm{pCi} / \mathrm{L})]\end{array}$ & $\begin{array}{c}\text { Gross } \alpha \\
(\mathbf{p C i} / \mathbf{L})\end{array}$ & $\begin{array}{c}\text { Gross } \beta \\
(p C i / L)\end{array}$ \\
\hline 306 & PS & PS-4 & $\mathrm{Grab}^{(\mathrm{b})}$ & $<600$ & $<2$ & 2.5 \\
\hline $318 / 320^{(\mathrm{c})}$ & PS & PS-33 & $\begin{array}{l}\text { 24-hr } \\
\text { Composite }\end{array}$ & $<600$ & $<2$ & $<3$ \\
\hline 325 & $\begin{array}{l}\text { Retention } \\
\text { Process } \\
\text { Sewer } \\
\text { (RPS) } \\
\end{array}$ & In building $^{(\mathrm{d})}$ & $\begin{array}{l}24-\mathrm{hr} \\
\text { Composite }\end{array}$ & $<600$ & $<2$ & $<3$ \\
\hline 325 & $\begin{array}{l}\text { Process } \\
\text { Water }^{(\mathrm{e})}\end{array}$ & In building & Grab & $<600$ & $<2$ & $<3$ \\
\hline 326 & PS & $\begin{array}{l}\text { In building } \\
\text { (PS-82) }\end{array}$ & $\begin{array}{l}\text { 24-hr } \\
\text { Composite }\end{array}$ & $<600$ & $<2$ & 3.2 \\
\hline 326 & RPS & In building & $\begin{array}{l}\text { 24-hr } \\
\text { Composite }\end{array}$ & $<600$ & $<2$ & 3.4 \\
\hline 329 & RPS & In building & $\begin{array}{l}\text { 24-hr } \\
\text { Composite }\end{array}$ & $<600$ & 2.4 & 3.8 \\
\hline 3720 & PS & PS-16 & $\mathrm{Grab}^{(\mathrm{f})}$ & $<600^{(\mathrm{g})}$ & $\begin{array}{l}341 \pm 11 \%(\mathrm{~h}) \\
257 \pm 12 \%\end{array}$ & $\begin{array}{l}182 \pm 13 \% \\
188 \pm 12 \%\end{array}$ \\
\hline \multicolumn{7}{|c|}{$\begin{array}{l}\text { (a) Samples run in duplicate. } \\
\text { (b) Combined 306W/306E stream. Too little flow for composite sampling. } \\
\text { (c) Combined stream from both buildings. } \\
\text { (d) Samples collected at established Pacific Northwest sampling locations. } \\
\text { (e) Process source water to determine background level. } \\
\text { (f) Too little flow for composite sampling at established sampling location. Sample collected further } \\
\text { upstream at a different manhole. This sample not believed to be representative of } 3720 \text { normal } \\
\text { discharges because it was a single grab sample at a low spot in the line and picked up sediments. } \\
\text { (g) Analyst indicated that none of the beta energy spectra for the tritium samples indicated the } \\
\text { presence of tritium. } \\
\text { (h) Uncertainty reported as 1-sigma. }\end{array}$} \\
\hline
\end{tabular}




\section{Appendix C}

\section{Treated Effluent Disposal Facility Waste Acceptance Criteria}


This page intentionally left blank.

Issued: June 2000

PNNL-13276, Rev. 2

Supersedes: Rev. 1

Page 48 


\section{Appendix C}

\section{Treated Effluent Disposal Facility Waste Acceptance Criteria}

The Treated Effluent Disposal Facility Waste Acceptance Criteria are listed below. These criteria are the same as those provided in the original Pacific Northwest National Laboratory Waste Certification Plan except that the limit for chloroform was increased from 26 micrograms per liter $(\mu \mathrm{g} / \mathrm{L})$ to $34 \mu \mathrm{g} / \mathrm{L}$ and a limit for total organic carbon (TOC) of $20 \mathrm{mg} / \mathrm{L}$ was added.

Table C.1. 300 Area Treated Effluent Disposal Facility Acceptance Criteria

\begin{tabular}{||l|l|c||}
\hline \multicolumn{1}{|c|}{ Constituent } & Units & Limit \\
\hline Bis(ethylhexyl) phthalate & $\mu \mathrm{g} / \mathrm{L}$ & 80 \\
\hline Bromodichloromethane & $\mu \mathrm{g} / \mathrm{L}$ & 4 \\
\hline Chlorodifluormethane & $\mu \mathrm{g} / \mathrm{L}$ & 7 \\
\hline Chloroform & $\mu \mathrm{g} / \mathrm{L}$ & 34 \\
\hline 1,1 - Dichloroethane & $\mu \mathrm{g} / \mathrm{L}$ & 7 \\
\hline Methylene chloride & $\mu \mathrm{g} / \mathrm{L}$ & 5 \\
\hline Tetrachloroethylene & $\mu \mathrm{g} / \mathrm{L}$ & 9 \\
\hline Toluene & $\mu \mathrm{g} / \mathrm{L}$ & 9 \\
\hline $1,1,1$ - Trichloroethane & $\mu \mathrm{g} / \mathrm{L}$ & 9 \\
\hline Trichloroethylene & $\mu \mathrm{g} / \mathrm{L}$ & 3 \\
\hline Aluminum & $\mu \mathrm{g} / \mathrm{L}$ & 418 \\
\hline Ammonia (total) & $\mu \mathrm{g} / \mathrm{L}$ & 1,800 \\
\hline Arsenic & $\mu \mathrm{g} / \mathrm{L}$ & 10 \\
\hline Beryllium & $\mu \mathrm{g} / \mathrm{L}$ & 30 \\
\hline Cadmium & $\mu \mathrm{g} / \mathrm{L}$ & 10 \\
\hline Copper & $\mu \mathrm{g} / \mathrm{L}$ & 80 \\
\hline Chromium & $\mu \mathrm{g} / \mathrm{L}$ & 50 \\
\hline Cyanide & $\mu \mathrm{g} / \mathrm{L}$ & 50 \\
\hline Iron & $\mu \mathrm{g} / \mathrm{L}$ & 1,460 \\
\hline Lead & $\mu \mathrm{g} / \mathrm{L}$ & 60 \\
\hline Manganese & $\mu \mathrm{g} / \mathrm{L}$ & 60 \\
\hline Mercury & $\mu \mathrm{g} / \mathrm{L}$ & 3 \\
\hline Nickel & & 60 \\
\hline \hline
\end{tabular}


Table C.1. (contd)

\begin{tabular}{||l|c|c||}
\hline \multicolumn{1}{|c|}{ Constituent } & Units & Limit \\
\hline Nitrite & $\mu \mathrm{g} / \mathrm{L}$ & 400 \\
\hline Selenium & $\mu \mathrm{g} / \mathrm{L}$ & 7 \\
\hline Silver & $\mu \mathrm{g} / \mathrm{L}$ & 20 \\
\hline Zinc & $\mu \mathrm{g} / \mathrm{L}$ & 210 \\
\hline TOC & $\mathrm{mg} / \mathrm{L}$ & 20 \\
\hline Coliform & $\mathrm{MPN} / 100 \mathrm{ml}$ & 146 \\
\hline pH & - & $6-11$ \\
\hline Suspended solids & $\mu \mathrm{g} / \mathrm{L}$ & 9,000 \\
\hline $\begin{array}{l}\text { Toxic pollutants (not otherwise limited } \\
\text { in waste acceptance criteria) }\end{array}$ & $\mu \mathrm{g} / \mathrm{L}$ & 100 \\
\hline Alpha activity & $\mathrm{pCi} / \mathrm{L}$ & 15 \\
\hline Beta activity & $\mathrm{pCi} / \mathrm{L}$ & 50 \\
\hline Gamma energy analysis & $\mathrm{pCi} / \mathrm{L}$ & 9,000 \\
\hline Tritium & $\mathrm{pCi} / \mathrm{L}$ & 20,000 \\
\hline Radium (total) & $\mathrm{pCi} / \mathrm{L}$ & 0.4 \\
\hline $\begin{array}{l}\text { pCi/L }=\text { picocuries per liter. } \\
\mu \mathrm{gg} / \mathrm{L}=\text { micrograms per liter. } \\
\text { mg/L = milligrams per liter. }\end{array}$ & \multicolumn{2}{|l}{} \\
\hline
\end{tabular}

In addition, toxic pollutants not specifically listed in the waste acceptance criteria are limited to 100 micrograms per liter. The list of toxic pollutants is provided in Table C.2.

Table C.2. Toxic Pollutants

\begin{tabular}{||l|l|l|l|l|l||}
\hline $\begin{array}{c}\text { Chemical } \\
\text { Compound }\end{array}$ & \multicolumn{1}{|c|}{ CAS \# } & \multicolumn{1}{c|}{$\begin{array}{c}\text { Chemical } \\
\text { Compound }\end{array}$} & \multicolumn{1}{c|}{ CAS \# } & \multicolumn{1}{c||}{$\begin{array}{c}\text { Chemical } \\
\text { Compound }\end{array}$} & \multicolumn{1}{c|}{ CAS \# } \\
\hline Antimony & 7440360 & Arsenic & 7440382 & Beryllium & 7440417 \\
\hline Cadmium & 7440439 & Chromium (III) & 16065831 & Chromium (VI) & 18540299 \\
\hline Copper & 7440508 & Lead & 7439921 & Mercury & 7439976 \\
\hline Nickel & 7440020 & Selenium & 7782492 & Silver & 7440224 \\
\hline Thallium & 7440280 & Zinc & 7440666 & Cyanide & 57125 \\
\hline Asbestos & 1332214 & $\begin{array}{l}2,3,7,8-\text { TCDD } \\
\text { (dioxin) }\end{array}$ & 1746016 & Acrolein & 107028 \\
\hline Acrylonitrile & 107131 & Benzene & 71432 & Bromoform & 75252 \\
\hline Carbon tetrachloride & 56235 & Chlorobenzene & 108907 & Chlorodibromethane & 124481 \\
\hline Chloroethane & 75003 & $\begin{array}{l}\text { 2-Chloroethylvinyl } \\
\text { ether }\end{array}$ & 110758 & Chloroform & 67663 \\
\hline
\end{tabular}


Table C.2. (contd)

\begin{tabular}{|c|c|c|c|c|c|}
\hline $\begin{array}{c}\text { Chemical } \\
\text { Compound }\end{array}$ & CAS \# & $\begin{array}{ll}\text { Chemical } \\
\text { Compound }\end{array}$ & CAS \# & $\begin{array}{l}\text { Chemical } \\
\text { Compound }\end{array}$ & CAS \# \\
\hline Dichlorobromethane & 75274 & 1,1-Dichloroethane & 75343 & 1,2-Dichloroethane & 107062 \\
\hline 1,1-Dichloroethylene & 75354 & 1,2-Dichloropropane & 78875 & 1,3-Dichloropropylene & 542756 \\
\hline Ethylbenzene & 100414 & Methyl bromide & 74839 & Methyl chloride & 74873 \\
\hline Methylene chloride & 75092 & $\begin{array}{l}1,1,2,2- \\
\text { Tetrachloroethane }\end{array}$ & 79345 & Tetrachloroethylene & 127184 \\
\hline Toluene & 108883 & $\begin{array}{l}\text { 1,2-Trans- } \\
\text { Dichloroethylene }\end{array}$ & 156605 & 1,1,1-Trichloroethane & 71556 \\
\hline 1,1,2-Trichloroethane & 79005 & Trichloroethylene & 79016 & Vinyl chloride & 75014 \\
\hline 2-Chlorophenol & 95578 & 2,4-Dichlorophenol & 120832 & 2,4-Dimethylphenol & 105679 \\
\hline $\begin{array}{l}\text { 2-Methyl-4,6- } \\
\text { dinitrophenol }\end{array}$ & 534521 & 2,4-Dinitrophenol & 51285 & 2-Nitrophenol & 88755 \\
\hline 4-Nitrophenol & 100027 & $\begin{array}{l}\text { 3-Methyl-4- } \\
\text { chlorophenol }\end{array}$ & 59507 & Pentachlorophenol & 87865 \\
\hline Phenol & 108952 & 2,4,6-Trichlorophenol & 88062 & Acenaphthene & 83329 \\
\hline Acenaphthylene & 208968 & Anthracene & 120127 & Benzidine & 92875 \\
\hline Benzo(a)anthracene & 56553 & Benzo(a)pyrene & 50328 & Benzo(b)fluorathene & 205992 \\
\hline Benzo(g,h,i)perylene & 191242 & Benzo(k)fluoranthene & 207089 & $\begin{array}{l}\text { Bis(2- } \\
\text { Chloroethoxy)methane }\end{array}$ & 111911 \\
\hline Bis(2-chlorethyl)ether & 111444 & $\begin{array}{l}\text { Bis(2- } \\
\text { chloroisopropyl)ether }\end{array}$ & 108601 & $\begin{array}{l}\text { Bis(2- } \\
\text { ethylhexyl)phthalate }\end{array}$ & 117817 \\
\hline $\begin{array}{l}\text { 4-Bromophenyl phenyl } \\
\text { ether }\end{array}$ & 101553 & Butylbenzyl phthalate & 85687 & 2-Chloronaphthalene & 91587 \\
\hline $\begin{array}{l}\text { 4-Chlorophenyl phenyl } \\
\text { ether }\end{array}$ & 7005723 & Chrysene & 218019 & $\begin{array}{l}\text { Dibenzo(a,h)anthracen } \\
\text { e }\end{array}$ & 53703 \\
\hline 1,2-Dichlorobenzene & 95501 & 1,3-Dichlorobenzene & 541731 & 1,4-Dichlorobenzene & 106467 \\
\hline 3,3'-Dichlorobenzidine & 91941 & Diethyl phthalate & 84662 & Diemthyl phthalate & 131113 \\
\hline Di-n-butyl phthalate & 84742 & 2,4-Dinitrotoluene & 121142 & 2,6-Dinitrotoluene & 606202 \\
\hline Di-n-Octyl phthalate & 117840 & 1,2-Dipenylhydrazine & 122667 & Fluoranthene & 206440 \\
\hline Fluorene & 867373 & Hexachlorobenzene & 118741 & Hexachlorobutadiene & 87683 \\
\hline $\begin{array}{l}\text { Hexachlorocyclopentad } \\
\text { iene }\end{array}$ & 77474 & Hexachloroehtane & 67721 & $\begin{array}{l}\text { Indeno(1,2,3- } \\
\text { cd)pyrene }\end{array}$ & 193395 \\
\hline Isophorone & 78591 & Napthalene & 91203 & Nitrobenzene & 98953 \\
\hline $\begin{array}{l}\mathrm{N}- \\
\text { Nitrosodimethylamine }\end{array}$ & 62759 & $\begin{array}{l}\text { N-Nitrosodi-n- } \\
\text { propylamine }\end{array}$ & 621647 & $\begin{array}{l}\mathrm{N}- \\
\text { Nitrosodiphenylamine }\end{array}$ & 86306 \\
\hline Phenanthrene & 85018 & Pyrene & 129000 & $\begin{array}{l}1,2,4- \\
\text { Trichlorobenzene }\end{array}$ & 120821 \\
\hline Aldrin & 309002 & alpha-BHC & 319846 & beta-BHC & 319857 \\
\hline Gamma-BHC & 58899 & delta-BHC & 319868 & Chlordane & 57749 \\
\hline $4-4$ '-DDT & 50293 & $4,4^{\prime}-\mathrm{DOE}$ & 72559 & $4,4^{\prime}-\mathrm{DDD}$ & 72548 \\
\hline Dieldrin & 60571 & alpha-Endosulfan & 959988 & beta-Endosulfan & 33213659 \\
\hline
\end{tabular}

Issued: June 2000

PNNL-13276, Rev. 2

Supersedes: Rev. 1

Page 51 
Table C.2. (contd)

\begin{tabular}{||l|l|l|l|l|l||}
\hline $\begin{array}{c}\text { Chemical } \\
\text { Compound }\end{array}$ & \multicolumn{1}{|c|}{ CAS \# } & \multicolumn{1}{c|}{$\begin{array}{c}\text { Chemical } \\
\text { Compound }\end{array}$} & \multicolumn{1}{c|}{ CAS \# } & \multicolumn{1}{c|}{$\begin{array}{c}\text { Chemical } \\
\text { Compound }\end{array}$} & CAS \# \\
\hline Endosulfan & 1031078 & Endrin & 72208 & Endrin aldehyde & 7421934 \\
\hline Heptachlor & 76448 & Heptachlor epoxide & 1024573 & PCB-1242 & 53469219 \\
\hline PCB-1254 & 11097691 & PCB-1221 & 11104282 & PCB-1232 & 11141165 \\
\hline PCB-1248 & 12672296 & PCB-1260 & 11096825 & PCB-1016 & 12674112 \\
\hline Toxaphene & 8001352 & & & \\
\hline CAS \# = Chemicals Abstract Service number. \\
\hline
\end{tabular}

